\title{
The Himalayan connection of the Middle Triassic brachiopod fauna from Socotra (Yemen)
}

\author{
Maurizio Gaetaniț, Marco Balini, Alda Nicora, Martino Giorgioni \& Giulio Pavia
}

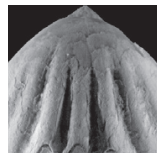

\begin{abstract}
The brachiopod fauna from the Middle Triassic beds of the Socotra Island, collected along the Ras Momi log, consists basically of four species, here described: Nudirostralina mutabilis (Stoliczka, 1866), Lepismatina lilangensis (Stoliczka, 1866), Spirigerellina stoliczkai (Bittner, 1899), Adygella socotrana sp. nov. Additional, very rare, species are Koeveskallina sp. and an undescribed very large dielasmatid. This fauna is arranged in three assemblages, with different age. The older is represented by Adygella socotrana and dated as Bithynian according to the presence of the conodonts Neogondolella regalis and Paragondolella bulgarica. The middle one is the richest in specimens, with lumachelle of Spirigerellina stoliczkai and rare specimens of other species. Its age is Illyrian on the base of several species of Paragondolellids and Neogondolellids, The younger one contains rare very large dielasmatid, Nudirostralina mutabilis, and Spirigerellina stoliczkai, which continues to be fairly abundant. The age of this assemblage is an indefinite Ladinian, due to the presence of Budurovignathus sp. This fauna is compared with a few specimens from Himalaya (G. lilangensis, S. stoliczkai, and "Dielasma" himalayanum), which were collected from the sections of Muth (Spiti), Phugtal (Zanskar), and Tulong (South Tibet). The brachiopod fauna of Socotra has an obvious counterpart with the Himalayan fauna, indicating a strong connection during the Middle Triassic. Our palaeobiogeographic interpretation is that Socotra was a part of the Indian Plate fringe or lying nearby during the Triassic. In the latest Triassic-Jurassic it was detached from the Indian margin with the Gondwana fragmentation, and then with the subsequent opening of the Indian Ocean in the Late Cretaceous. Socotra remained attached to the Arabian Peninsula until the opening of the Gulf of Aden in the Miocene. This separated Socotra from the Arabian Peninsula and left it as the easternmost tip of the Somali Plateau. Key words: palaeontology, palaeobiogeography, brachiopods, Triassic, Yemen, Himalaya.
\end{abstract}

Gaetani, M., Balini, M., Nicora, A., Giorgioni, M. \& Pavia, G. 2018. The Himalayan connection of the Middle Triassic brachiopod fauna from Socotra (Yemen). Bulletin of Geosciences 93(2), 247-268 (16 figures, 3 tables). Czech Geological Survey, Prague. ISSN 1214-1119. Manuscript received April 11, 2017; accepted in revised form October 10, 2017; published online June 20, 2018; issued June 30, 2018.

Maurizio Gaetani, deceased December 19, 2017 - Marco Balini \& Alda Nicora, Dipartimento di Scienze della Terra, Via Mangiagalli 34, 20133 Milano, Italia; Marco.balini@unimi.it• Martino Giorgioni, Instituto de Geociências da Universidade de Brasília, Campus Universitário Darcy Ribeiro ICC-Ala Central, 70910-900, Brasília (DF), Brazil • Giulio Pavia, Dipartimento di Scienze della Terra, Via Valperga Caluso 35, 10125, Torino, Italia

The Socotra Island (Yemen) is located out of the coast of the East African corner of Somalia, and presents the main geological features of South Oman (Dofhar Mountains) as well as the sedimentary cover of southern Yemen. However, the sedimentary succession of Socotra is of particular interest for the Triassic, as it represents the only location in the southern Middle East with outcropping marine facies of this period. These sediments were described for the first time by Samuel et al. (1997), within an oil prospecting study, but no detailed litho- and biostratigraphic study has been presented so far.

The general stratigraphy of the Triassic succession of Socotra was studied in the master thesis of Giorgioni (2006), and preliminary results were presented by Balini et al. (2008). Several brachiopod specimens were collected by M. Balini and G. Pavia in 2004 and by M. Gaetani,
M. Balini, and M. Giorgioni in 2005. Here we present the taxonomic description and palaeobiogeographic significance of the brachiopod fauna recovered in the Triassic succession of the Socotra Island, while detailed lithofacies, ammonoid, and conodont descriptions will be presented by M. Balini and A. Nicora in another work.

The aim of this paper is twofold: (i) illustrate the Triassic brachiopod assemblages of the Socotra Island and constrain their time of occurrence on the base of conodont biostratigraphic dating and (ii) discuss the affinities of the Triassic brachiopods from Socotra with the time equivalent fauna from Himalaya (India, Nepal, and Tibet), as well as their paleobiogeographic implications.

We show that the brachiopod assemblages found in Socotra have a strong affinity with those from Himalaya, 


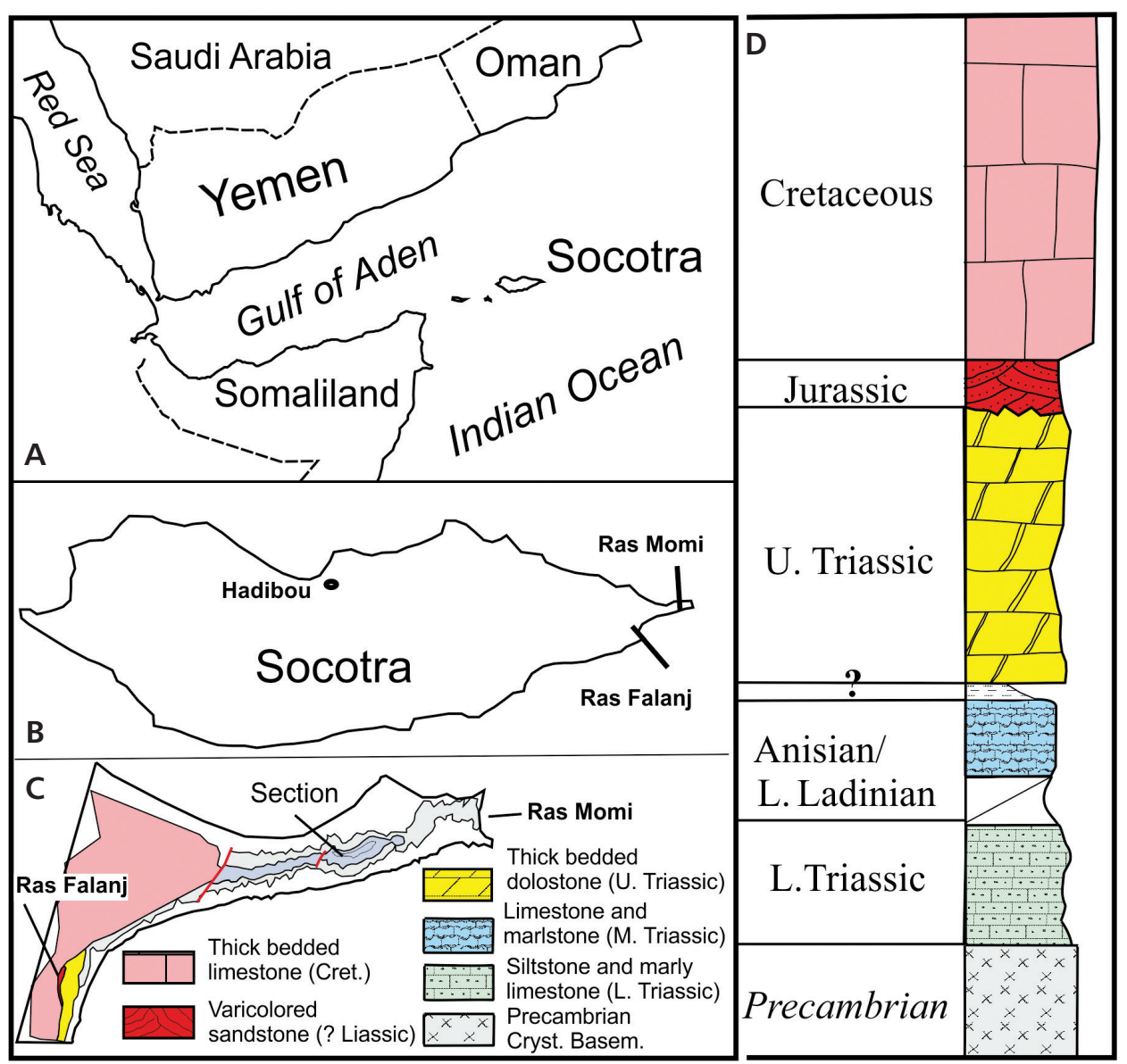

Figure 1. The island of Socotra (A), the position of studied section at the eastern tip of the island (B), geological sketch of the area Ras Momi-Ras Falanj (C), and a general scheme of the Mesozoic sedimentary succession in the eastern part of the island (D).

indicating a strong connection between the two provinces during the Triassic.

\section{Sedimentary succession of Socotra}

The sedimentary succession of the Socotra Island lies non-conformably over a magmatic and metamorphic basement of late Precambrian age (Beydoun \& Bichan 1969, Samuel et al. 1997). The Triassic portion outcrops only in the easternmost tip of the island and is best exposed in two locations: Ras Momi and Ras Falanj. The main lithostratigraphic units, shown in Fig. 1, consist of (from base to top):

(1) Conglomerates and sandstones, overlain by alternated shale, light grey skeletal carbonate, and marlstone. About $110 \mathrm{~m}$ thick. Conodonts found the carbonate facies, with good to excellent state of preservation, indicate an age ranging from Smithian (early Olenekian) to latest Anisian and Ladinian.

(2) Green shale, very poorly exposed, some tens of metres thick. Barren at the palynological analysis.

(3) Light dolostone, with beds $10 \mathrm{~cm}$ to $80 \mathrm{~cm}$ thick, arranged in m-thick bundles. The total thickness is about $100 \mathrm{~m}$ and the estimated age is Late Triassic, on the base of moulds of megalodontids.

(4) A major hiatus occurs above the Triassic units encompassing the uppermost part of the Triassic and lowermost of the Jurassic (Samuel et al. 1997).

(5) Cross-bedded coarse sandstones and fine conglomerates, often pink to reddish, a few tens of $m$ thick. The age is estimated as Lower to Middle Jurassic, based on the affinity with the Karoo Formation or Adigrat Sandstone (Merla

Figure 2. The section of Ras Momi with the range of the studied brachiopods and the most significant conodonts species. 


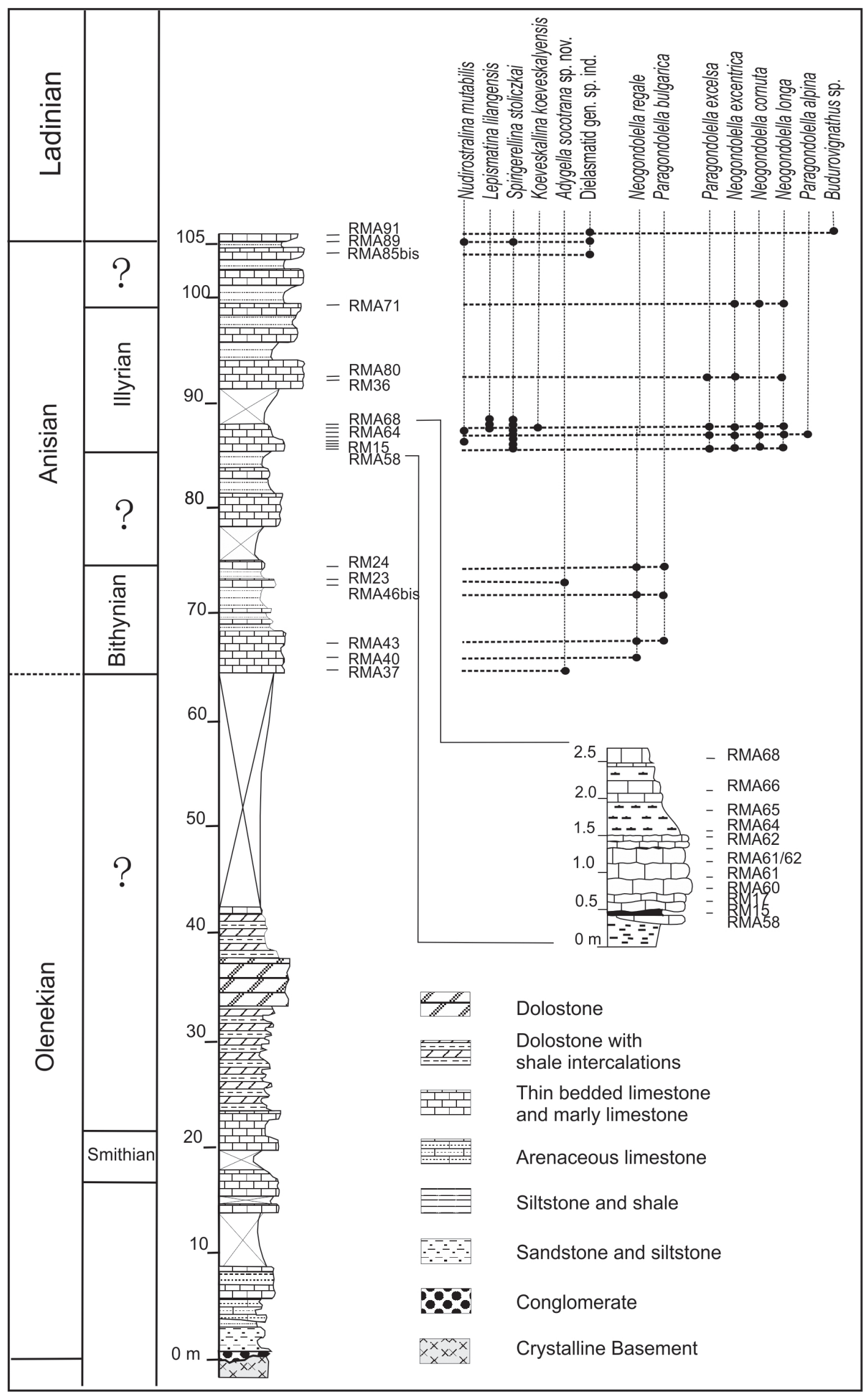


et al. 1979), and the overlying limestone layers with Toarcian microfauna (Banner et al. 1997).

(6) A major hiatus separates the former unit from the following, encompassing most part of the Jurassic and the lower part of the Lower Cretaceous (Samuel et al. 1997).

(7) Thick-bedded limestone and dolostone, forming the backbone of the island, several hundred metres thick. The age is estimated as mid Cretaceous (Barremian to Cenomanian; Morrison et al. 1997, Samuel et al. 1997).

(8) Cenozoic units are not present in the studied locations, but occur mainly in the western part of the island (Samuel et al. 1997).

Brachiopods fossils were found only in the lower part of the succession, which is the best preserved and exposed at Ras Momi, No brachiopods were collected at Ras Falanj, where mostly the upper part of the succession is exposed and the lithology is pervaded by intense dolomitization that overprinted all the primary features. Here we focus only on the section of Ras Momi, as it is the only that yielded well preserved brachiopods.

\section{Ras Momi section}

The Ras Momi section is located in the easternmost tip of the Socotra Island, the Momi Peninsula. The outcrop lies along the upper part of a ridge that crosses the peninsula longitudinally, from east to west, and reaches a maximum altitude of $350 \mathrm{~m}$. The succession begins from the contact with the basement and continues almost undisturbed up to $104 \mathrm{~m}$. The bedding is exposed in a monoclinal series with orientation of $150^{\circ} / 18^{\circ}$ (Fig. 2).

The lithostratigraphy, from the base to the top, is as follows:

Basement: Metasediments and amphibolites intruded by gabbros and acid intrusives. It is late Precambrian in age, according to Beydoun \& Bichan (1969) and Samuel et al. (1997).

(1) A deepening upward sequence, about $10 \mathrm{~m}$ thick, starting with a conglomerate layer, overlain by fine sandstone and platy limestone.

(2) About $40 \mathrm{~m}$ of thin-bedded platy limestone, progressively dolomitized and arranged in thickening upward cycles of $2 \mathrm{~m}$ to $5 \mathrm{~m}$. Both the beds and cycle thicknesses increase gradually from the base to the top of this interval. The conodonts etched out yielded the Smithian age.
(3) About $60 \mathrm{~cm}$ of calcarenites with intraclasts and oncolites, locally cross-laminated, followed by more than $20 \mathrm{~m}$ of a barely cropping clayey marl.

(4) Bundles up to $5 \mathrm{~m}$ thick of thin-bedded nodular limestone, often bioturbated, alternating with grey-yellow marlstone. The entire interval is about $45 \mathrm{~m}$ thick, very rich in fossils, and dated with conodonts as Anisian (Bithynian to Illyrian). All the brachiopods presented in this work were collected from this interval.

The section ends at the summit of the ridge, where the succession is truncated by a normal fault.

\section{Triassic brachiopod fauna of Socotra}

We identified three brachiopod assemblages, occurring from the base to the top of the studied interval (Fig. 3).

(1) Adygella socotrana Assemblage. It occurs between $68 \mathrm{~m}$ and $78 \mathrm{~m}$ from the base of the section, where a high frequency of Adygella socotrana sp. nov. has been observed (samples RMA37 and RM23, 68 specimens collected). The specimens are usually articulated and sparse within the marlstone and thin limestone beds. No other brachiopod species were found. Isolated fragments of crinoids are also present. This assemblage is accompanied by the conodonts Neogondolella regalis (sample RMA40), Neogondolella regalis and Paragondolella bulgarica (samples RMA43 to RMA46bis, and RM24); which suggest a Bithynian age (Nicora 1977).

(2) Spirigerellina stoliczkai lumachelle Assemblage. The interval between $88 \mathrm{~m}$ and $91 \mathrm{~m}$ from the base is the richest in brachiopod specimens, absolutely dominated by Spirigerellina stoliczkai (Bittner, 1899). Thousands of specimens were observed throughout the bed surfaces (RMA 58 to 68; Figs 2, 4). Brachiopod fossils occur mostly articulated, but also partly abraded and with rare bryozoan incrustations. They seem mechanically accumulated in a very shallow environment, locally forming shell lags. Sporadic partly silicified specimens may also occur (RMA 66). Locally intense burrowing was also observed.

Other accompanying brachiopod species consist of rare Lepismatina lilangensis (Bittner, 1899), very rare Nudirostralina mutabilis (Stoliczka, 1866) and a single valve of Koeveskallina cf. koeveskalyensis (Stur, 1865). The carbonate sandy bottom of this interval favoured the blossom of pedunculated brachiopods. Lepismatina lilangensis is often fragmented and disarticulated, because of its delicate shell. Ventral valves prevail. In the upper part of this interval, the specimen density decreases, as the sediments 
Figure 3. A - oblique satellite imagery view of the Ras Momi section with the position of brachiopod assemblages (Google Earth image). • B - view of the section from the sea.

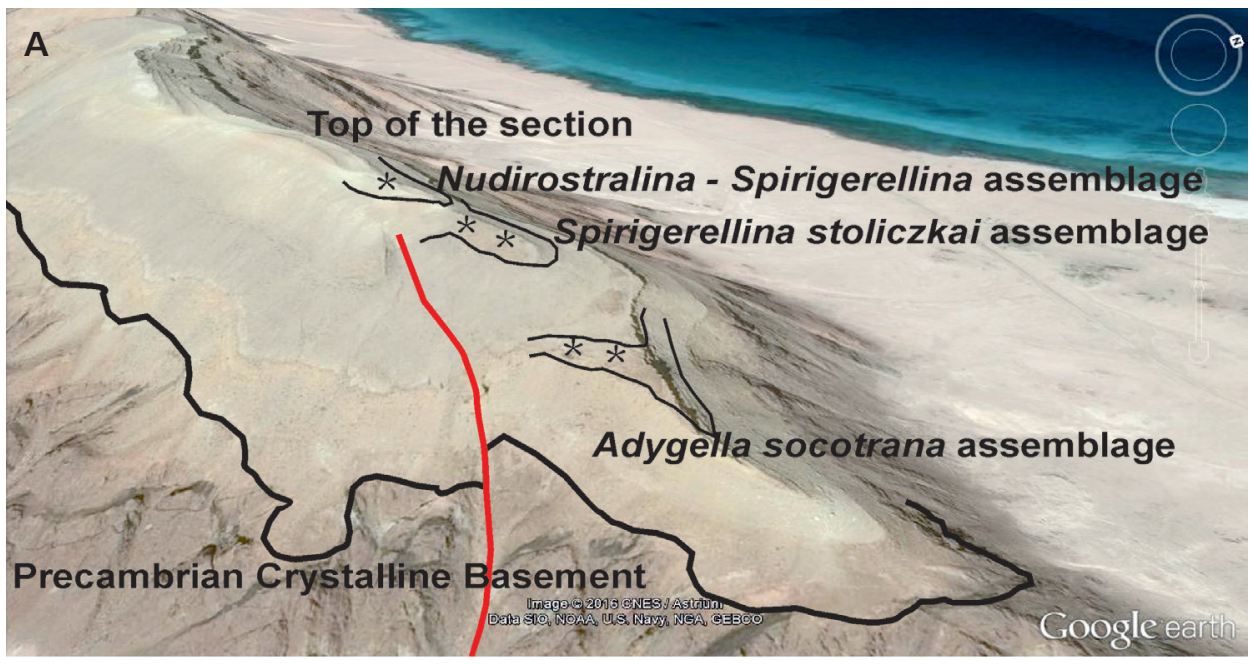

B
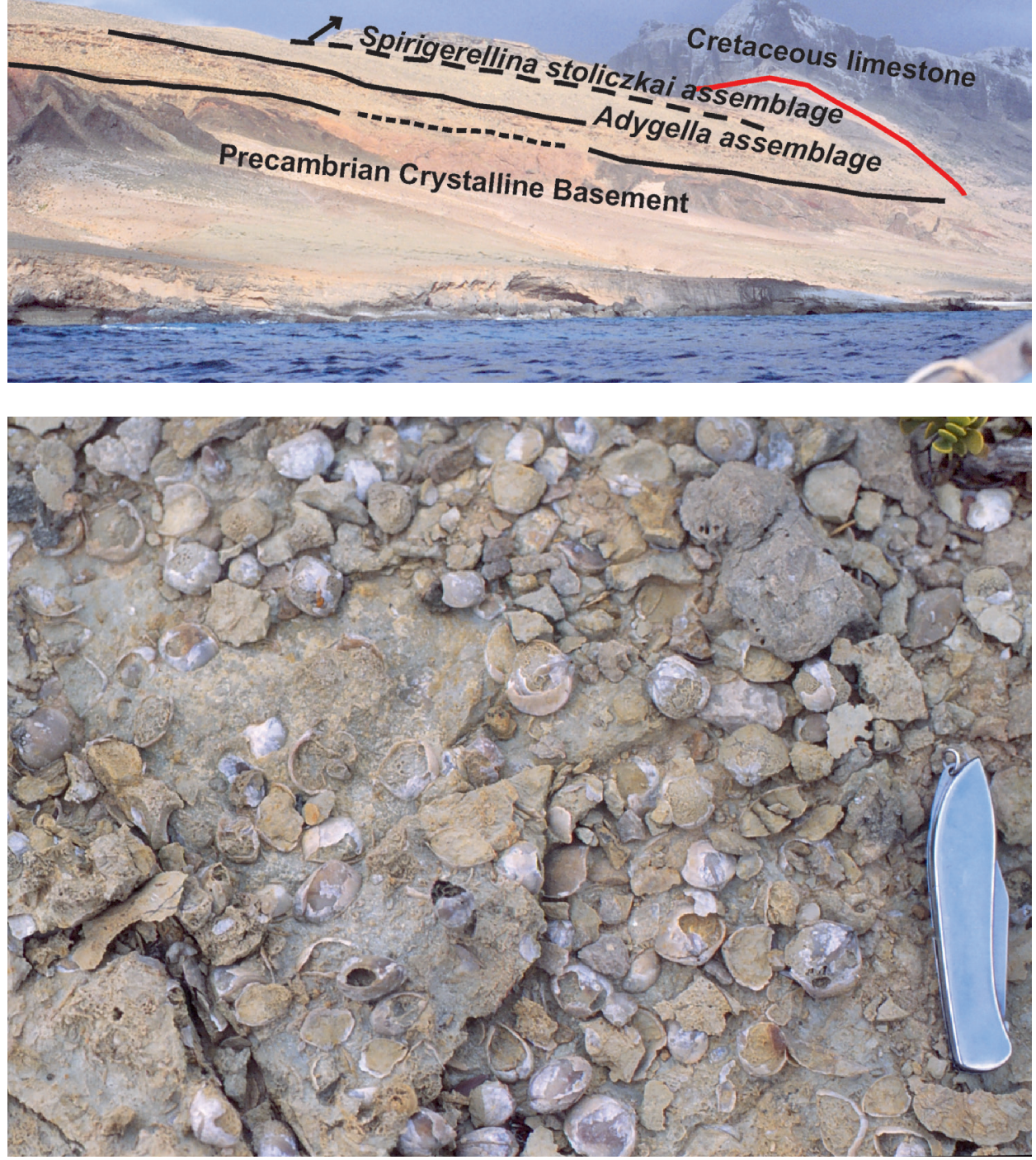

Figure 4. Lumachelle bed with Spirigerellina stoliczkai (Bittner, 1899). Bed RMA 64/65, Ras Momi section. The knife for scale is $9.4 \mathrm{~cm}$ long. 
became muddier. Conodonts are also abundant, with Paragondolella excelsa, P. liebermani, P. fueloepi, Neogondolella pseudobifurcata, N. excentrica, and N. balcanica, which show the Illyrian age (Kozur \& Mostler 1982, Kovács 1994, Nicora \& Brack 1995, Brack et al. 2005).

This conodont/brachiopod assemblage continues upward, up to $103 \mathrm{~m}$ from the base, with less abundant occurrences. The conodonts N. pseudobifurcata, N. excentrica, $N$. longa, and $N$. cornuta continue up to the sample RMA71, still indicating an Illyrian age.

(3) Nudirostralina mutabilis-Spirigerellina stoliczkai Assemblage. The last faunal assemblage is restricted to the top of the section, where Nudirostralina mutabilis is frequent and Spirigerellina stoliczkai is still abundant, even though frequently fragmented. Very large dielasmatids, disarticulated and fragmented, occur here for the first time. A muddier bottom characterizes the environment of this last occurring assemblage. Specimens are sparse or form small pocket accumulations. The presence of Budurovignathus sp. suggests an Early Ladinian age (Kovács 1983, Krystyn 1983, Kozur et al. 1994, Nicora \& Brack 1995, Brack et al. 2005).

In conclusion, the brachiopod faunas from the Ras Momi section encompass three major assemblages and span from the Bithynian (Early Anisian) to an indefinite Early Ladinian.

\section{Triassic successions of Himalaya}

We compared the brachiopods found in Socotra with specimens from the Himalayan sections of Muth (Spiti), Phugtal (Zanskar), and Tulong (South Tibet). Brachiopods in these sections are always rare; therefore the comparison is based on few specimens.

Brachiopods from Muth, collected by M. Balini, were classified as Spirigerellina stoliczkai, Lepismatina lilangensis, and "Dielasma" himalayanum. All the specimens are from the bed E 37, near the top of the Himalayan Muschelkalk Member of the Mikin Formation. According to Krystyn et al. (2004), this bed represents the topmost part of the Bithynian.

Brachiopods collected by M. Gaetani from the Phugtal section, in Zanskar, are poorly preserved. However, it was possible to recognize Nudirostralina ex gr. mutabilis, Koeveskallina sp., Lepismatina sp., Spirigerellina sp., and "Dielasma" himalayanum. This assemblage was found in the basal beds of the upper member of the Tamba Kurkur Fm., considered of Pelsonian age (Nicora et al. 1985, Gaetani et al. 1986).

We also considered three specimens of "Dielasma" himalayanum (Bittner, 1899), kindly provided by E. Gar- zanti and collected along the Tulong section in South Tibet. These specimens are from the 22 basal metres of the Qudenggongba Fm. (Garzanti et al. 1998, p. 148), which is dated as Bithynian-Pelsonian (E. Garzanti, personal communication).

\section{Systematic palaeontology}

(M. Gaetani $\dagger$ )

Repository. - The material described here is housed in the Museo di Paleontologia dell'Università di Milano (MPUM). Samples have been coded with the label RM or RMA and are followed by the figure. The classification was performed according to the Treatise on Invertebrate Paleontology, part $\mathrm{H}$, volumes 4 and 5 (Williams et al. 2002, 2006).

Phylum Brachiopoda Duméril, 1806

Subphylum Rhynchonelliformea Williams, Carlson, Brunton, Holmer \& Popov, 1996

Class Rhynchonellata Williams, Carlson, Brunton, Holmer \& Popov, 1996

Order Rhynchonellida Kuhn, 1949

Superfamily Rhynchonelloidea d'Orbigny, 1847

Family Rhynchonellidae d'Orbigny, 1847

\section{Genus Nudirostralina Yang \& Xu, 1966}

Type species. - Nudrostralina subtrinodosi Yang \& Xu, 1966. Anisian of Qingyen, Gueiyang, SW China.

\section{Nudirostralina mutabilis (Stoliczka, 1866)}

Figures 5A-F, 6

1866 Rhynchonella mutabilis Stoliczka, p. 40, pl. 3, figs 5-9. 1899 Rhynchonella mutabilis Stoliczka, 1866. - Bittner, p. 15, pl. 2, figs 11-13.

1907 Rhynchonella mutabilis Stoliczka, 1866. - Diener, p. 6.

? 1976 Nudirostralina mutabilis Stoliczka, 1866. - Jin \& Sun in Jin et al., p. 289, pl. 2, figs 6, 7.

Material. - Section Ras Momi: MPUM 11530, RMA 62 (1 spec.); MPUM 11531, RMA 65 (1 spec.); MPUM 11532 RMA 89 (24 spec.). Mostly articulated specimens.

Description. - Small to medium biconvex shell, with length similar or slightly exceeding width, uniplicate. Ventral valve with erect beak, foramen submesothyrid, small discrete deltidial plates. Sulcus originating at mid of the length, sharply delimited on the flanks.

Dorsal valve much thicker than the ventral, with thickness gradually growing up to the front. Fold present from the mid of the length. 


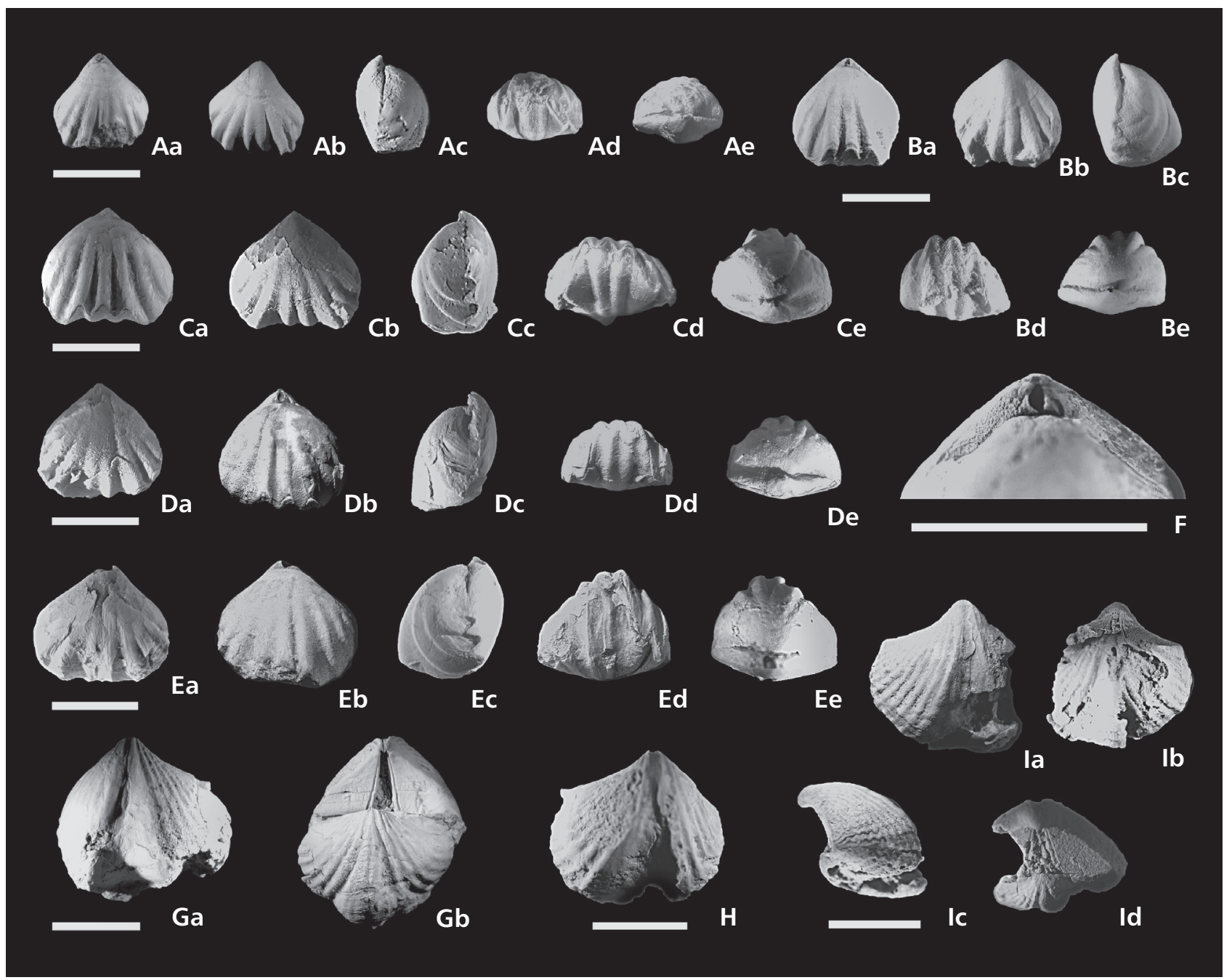

Figure 5. A-F - Nudirostralina mutabilis (Stoliczka, 1866). Scale bar $=1 \mathrm{~cm} ; \mathrm{Aa}-\mathrm{e}-$ dorsal, ventral, lateral, anterior, and posterior views, respectively. Specimen RMA 89/6. MPUM11532; Ba-e - dorsal, ventral, lateral, anterior, and posterior views, respectively. Specimen RMA 89/3. MPUM11532; $\mathrm{Ca}-\mathrm{e}$ - dorsal, ventral, lateral, anterior, and posterior views, respectively. Specimen RMA 89/5. MPUM11532; Da-e - dorsal, ventral, lateral, anterior, and posterior views, respectively. Specimen RMA 89/4. MPUM11532; Ea-e - dorsal, ventral, lateral, anterior, and posterior views, respectively. Specimen RMA 89/7. MPUM11532; F - detail of the umbo, with permesothyrid foramen. Specimen RMA 89/4. MPUM11532. - G-I - Lepismatina lilangensis (Bittner, 1899); Ga, b - ventral and dorsal view, respectively. Specimen RMA 66/1. MPUM 11535; H - ventral view. Specimen RMA 66/2. MPUM 11535; Ia-d - ventral, dorsal, lateral, and posterior view, respectively. Specimen 64/6. MPUM 11533.

Ornaments made by simple angular costae, originating around mid of the length. The median costae have ratio $3 / 2$ in 18 specimens, and 2/1 in 7 specimens. Dimensions (in $\mathrm{mm}$ ) of the Nudirostralina mutabilis (Stoliczka, 1866) are listed in Table 1.

Internal features: The sectioned specimens are partly deformed and recrystallized. The quality of observation is rather poor. The ventral valve has dental plates, posteriorly markedly divergent, then more parallel and vertical. The dental plates bear bifid teeth and denticula. Lateral cavities open. Dorsal valve with deep septalium, high inner socket ridges and rather long median septum. Crural bases triangular, but poorly visible.
Remarks. - Without additional specimens from Himalaya at hand, it is difficult to assess the taxonomy of the rhynchonellids described by Bittner (1899). Nudirostralina mutabilis is described as similar to the smoother Piarorhynchella trinodosi. However, from the plate 2, figs 11-14 of Bittner (1899) the shell of N. mutabilis looks covered by costae originating at least at mid of the length. Also P. trinodosi of Diener (1907, pl. 1, fig. 1) has costae starting already before mid-length. In P. trinodosi from the Southern Alps, type-area of the species, the shell is smoother and costae start after the mid length (Gaetani 1969).

It is possible that, on the base of a larger collection, the three species, griesbachi (Bittner, 1899), dieneri (Bittner, 1899), 

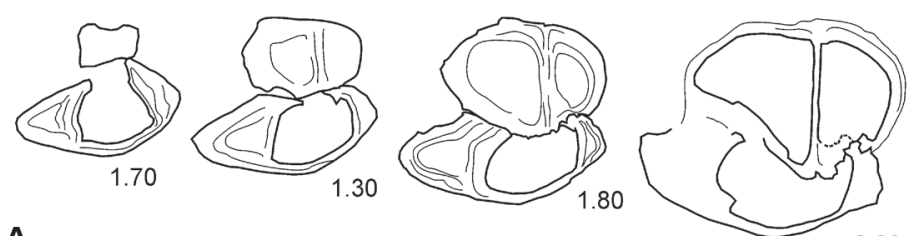

A

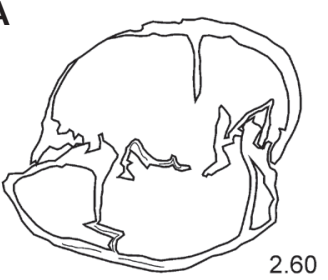

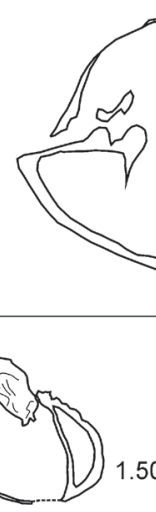

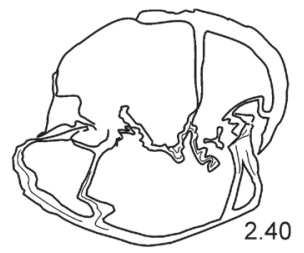

Figure 6. Nudirostralina mutabilis (Stoliczka, 1866). Serial sections. Distance from the umbo in $\mathrm{mm}$. Scale bar $=1 \mathrm{~cm} ; \mathrm{A}-$ specimen RMA 65/1, MPUM 11531; B - specimen RMA 89/9, MPUM 11532.

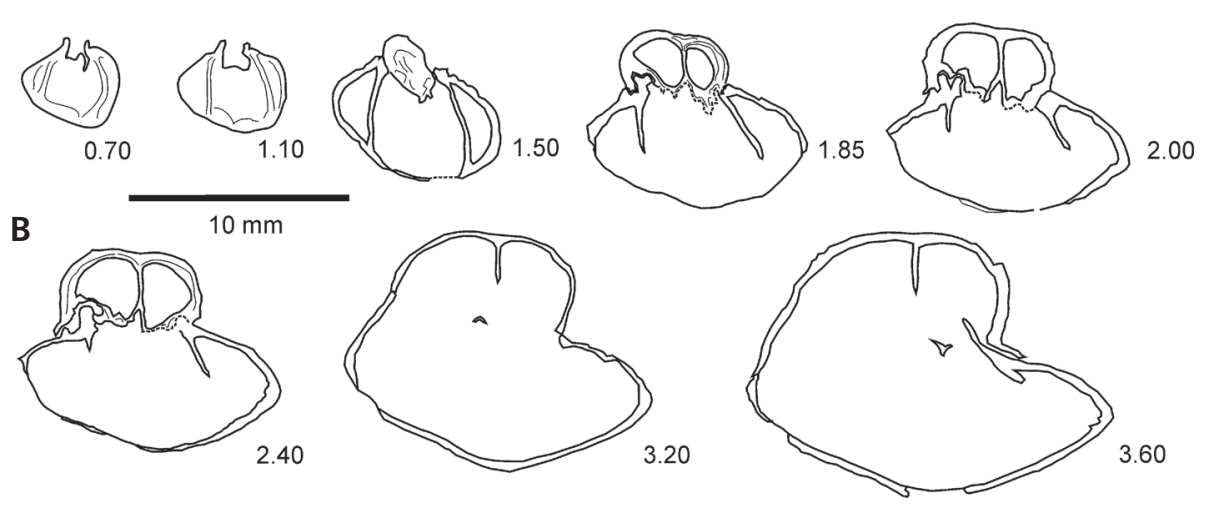

and mutabilis will result as different ontogenic stages of the same species. In such a case, mutabilis will have priority. Piarorhynchella trinodosi (Bittner, 1890) sometimes reported also from Western Himalaya, has smoother shell, with costae originating more toward the front, with median costae dominated by the ratio $1 / 2$ (Gaetani 1969). In $N$. mutabilis the ratio $2 / 3$ prevails. The $N$. mutabilis figured by Jin and Sun in Jin et al. (1976) is poorly depicted and deformed.

Occurrence. - Socotra, brachiopod assemblages 2 and 3: Illyrian to earliest Ladinian. In Himalaya, N. mutabilis was described from the Himalayan Muschelkalk of Spiti, Bithynian/Pelsonian in age (Bittner 1899).

Order Spiriferida Waagen, 1883

Suborder Spiriferinida Ivanova, 1972

Superfamily Pennospiriferinoidea Dagys, 1972

Family Lepismatidae Xu \& Liu, 1983

\section{Genus Lepismatina Wang, 1955}

Type species. - Lepismatina hsui Wang, 1955.

\section{Lepismatina lilangensis (Stoliczka, 1866)}

Figure 5G-I
1866 Spirifer (Spiriferina) lilangensis Stoliczka, p. 38, pl. 3, fig. 4.

1899 Spiriferina lilangensis Stoliczka 1866. - Bittner, p. 20, pl. 4, fig. 2.

Material. - Ras Momi: MPUM 11533, RMA 64 (1 spec.); MPUM 11534 RMA 65 (2 spec.); MPUM 11535, RMA66 (2 spec.); MPUM 11536 RMA 68 (3 spec.). Muth, Spiti, India: MPUM 11537, E37. The specimens are mostly disarticulated and the ventral valve is more frequent. Only one specimen is articulated. Very fragile shell.

Description. - Small to medium sized spiriferinid, width about double of the length; maximum width at $1 / 3$ of the length. Hinge with rounded ends, never mucronate. Ventral valve triangular in lateral outline, with high slightly apsacline interarea. Deep delthyrial grooves. Wide median sulcus, labiate at the front. Dorsal valve thick about half of the ventral thickness, with gentle median fold. Ornaments made by angular costae on the flanks, $7-8$ on each side. Sulcus and fold smooth. Shell punctate.

No serial sections were possible. On a fragmentary specimen, the median septum and the two long divergent dental lamellae may be observed.

Remarks. - In the Anisian of Himalaya Tulungospirifer 
Table 1. Dimensions (in mm) of the Nudirostralina mutabilis (Stoliczka, 1866).

\begin{tabular}{lcccc}
\hline Specimen & Length & Width & Thickness & Costae ratio \\
\hline RMA62 & 12.9 & 12.9 & 7.7 & $2 / 3 ; 3 / 2$ \\
RMA 65 & 12.7 & 13.4 deformed & 9.2 & $2 / 3 ; 3 / 2$ \\
RMA 89/1 & 12.0 & 11.9 & 9.4 & $2 / 3 ; 3 / 2$ \\
RMA 89/2 & 12.9 & 12.7 & 9.2 & $1 / 2 ; 2 / 1$ \\
RMA89/3 & 13.2 & 12.6 & 9.6 & $2 / 3 ; 3 / 2$ \\
RMA 89/4 & 14.2 & 13.6 & 9.7 & $2 / 3 ; 3 / 2$ \\
RMA 89/5 & 13.4 & 14.8 & 10.7 & $2 / 3 ; 3 / 2$ \\
\hline
\end{tabular}

stracheyi (Salter, 1865) has shape with extended mucronate hinge and coarser costae. Punctospirella fragilis (Schlotheim, 1813) has slightly coarser ribs, usually in number of five on each side, and with more curved interarea. Lepismatina lilangensis has non-mucronate shape and slightly thinner costae, up to seven on each flank. The dental lamellae are attached together at mid length, and are not discrete as in Punctospirella. Lepismatina manca (Bittner, 1890) has different internal dental lamellae.

Occurrence. - Socotra, brachiopod assemblages 2 and 3. Lalung (Lilang) in Spiti, Western Himalaya (Bittner, 1899). Top of the Himalayan Muschelkalk at Muth (Spiti, Bed E37) (Krystyn et al. 2004). Bithynian/Pelsonian in Spiti, Illyrian in Socotra.

Order Athyridida Boucot, Johnson \& Staton, 1964 Suborder Athyrididina Boucot, Johnson \& Staton, 1964 Superfamily Athyridoidea Davidson, 1881

Family Diplospirellidae Schuchert, 1894

Subfamily Ochotathyridinae Alvarez, Rong \& Boucot, 1998

\section{Genus Spirigerellina Dagys, 1974}

Type species. - Spirigerellina pygmaea Dagys, 1974. Olenekian of Mangyshlak, Kazakstan.

\section{Spirigerellina stoliczkai (Bittner, 1899)}

Figures 7A-I, 8, 9, 10.

1898 Spirigera (Athyris) Stoliczkai Bittner, p. 691. [nomen nudum]

1899 Spirigera (Athyris) Stoliczkai Bittner 1899, p. 23, pl. 3, figs 1-17.

1907 Spirigera Stoliczkai Bittner, 1899. - Diener, p. 3.

non 1928 Spirigera stoliczkai Bittner, 1899. - Parona, p. 21, pl. 2, figs 6, 7 .

non 1928 Spirigera stoliczkai var. prehunica Bittner, 1899. Parona, p. 21, pl. 2, fig. 8.
1975 Spirigerellina stoliczkai Bittner, 1899. - Siblík, p. 145, figs 6,7 ; pl. 21, figs $1-3$.

Material. - Socotra Island: about 370 specimens. MPUM 11538, RM17 top (= RMA60) (41 spec.); MPUM11539, RM41 (7 spec.); MPUM11540, RMA58 (5 spec.); MPUM11541, RMA60 (10 sp.); MPUM11542, RMA61 (31 spec.); MPUM11543, RMA61/62 (96 spec.); MPUM11544, RMA 62 (26 spec.); MPUM11545, RMA64 (5 spec.); MPUM11546, RMA65 (65 spec.); MPUM11547, RMA68 (29 spec.); MPUM11 548, RMA89 (58 spec.). Specimens are usually articulated, only in RMA89 some is distorted and disarticulated. Muth, Spiti, Western Himalaya: MPUM11549, E37 (3 specimens).

Description. - Smooth biconvex shell, subpentagonal in outline, with width usually larger than length. The height rapidly increases with size; the gerontic specimens have a bump in the dorsal valve towards the front in lateral view. Strongly uniplicate, with fold and sulcus well defined but not sharply delimited and visible since half to $2 / 3$ rd of the length. Cardinal hinge gently curved. Foramen closed by deltidial plates towards the hinge in permesothyrid position. Dorsal muscle field with median adductors very narrow and elongated, gently subdivided by the myophragm, and larger but shorter external adductors. Diductors reaching half of the length of the valve in the ventral valve (Fig. $7 \mathrm{Bb}$ ). Mantle channels rectilinear and well separated (Fig. 7Aa).

Growing lamellae visible only on well-preserved specimens. Fine radial striae, about $18-20$ on $5 \mathrm{~mm}$ at the front, on slightly decorticated specimens (Fig. 7F). Shell impunctated. Scatter plots of length vs width and thickness vs width are reported in Fig. 8.

Internal features: Ventral valve with subparallel dental lamellae, vertically extending from the flank of the delthyrium for about the $1 / 8$ of the length. Delthyrial cavity subquadrate. Lateral cavities open. Teeth simple, not crenulated, inserted in the sockets with low angle. Small and short denticula. 


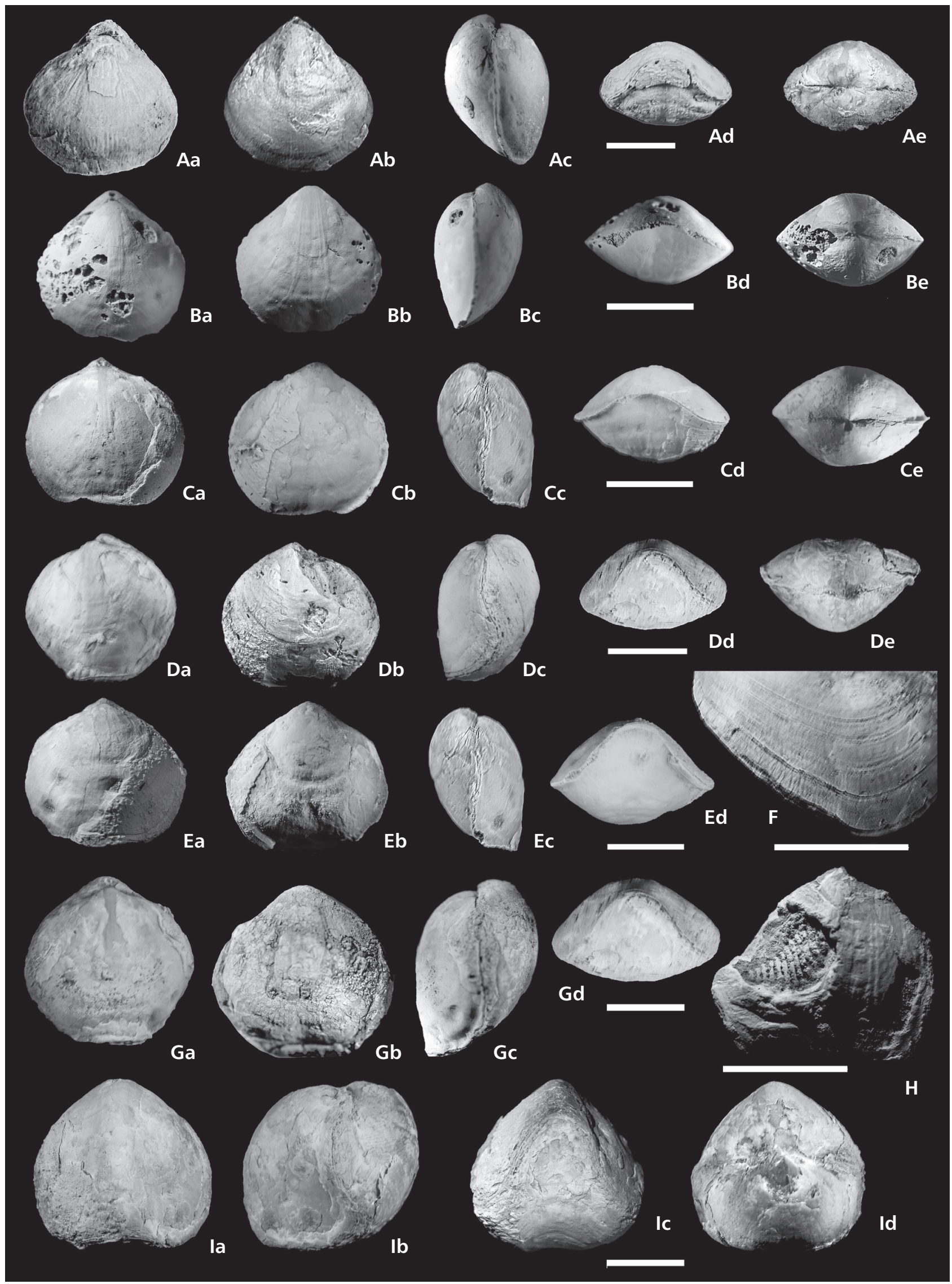


Dorsal valve with very strong cardinal process and thick hinge plate, ending laterally in two wings that form the inner socket ridges. Outer socket ridges poorly developed, almost flat. Posterior open coelomic cavity, with no septum; only a gentle myophragm visible forward.

Crural basis gently inclined towards the centre of the cavity. The spiralia were always broken in the four specimens sectioned from Socotra, while the specimen from Spiti is heavy recrystallized. Spiralia with at least eleven volutions in a decorticated specimen (Fig. 7H).

Remarks. - The shape and the internal features match well with definition of the genus Spirigerellina Dagys, 1974. On the other hand, there are differences with the serial sections of Siblík (1975), because our sectioned specimens do not have the median septum in the dorsal valve and have instead open posterior coelomic cavity. The sectioned specimen E37/2 from Muth, seems to have the coelomic cavity open, as it was reported in Bittner $(1899$, pl. 2, fig. 9). The recrystallization, however, prevents a more accurate investigation.

Occurrence. - Spirigerellina stoliczkai is very frequent in Socotra, brachiopod assemblages 2 and 3. It is known through Western and Central Himalaya, from Spiti (Rimkin Fm., Himalayan Muschelkalk Mb. to RimkiPajar (Kumaon), and Dolpo (Mukut Lmst.) in Nepal. The Karakorum Pass occurrence (Parona 1928) is not correct, after checking (MG) of the material stored in the Florence Museum. Dagys (1974) reports this species also from Primorye. The age is Illyrian to earliest Ladinian in Socotra, Bithynian to Pelsonian in Himalaya.

Order Terebratulida Waagen, 1883

Suborder Terebratulidina Waagen, 1883

Superfamily Dielasmatoidea Schuchert, 1913

Family Dielasmatidae Schuchert, 1913

\section{Genus Dielasma King, 1859}

Type species. - Terebratulites elongatus Schlotheim, 1816. Upper Permian of Thuringia, Germany.

\section{"Dielasma" himalayanum Bittner, 1899}

Figures 11A, B, 12
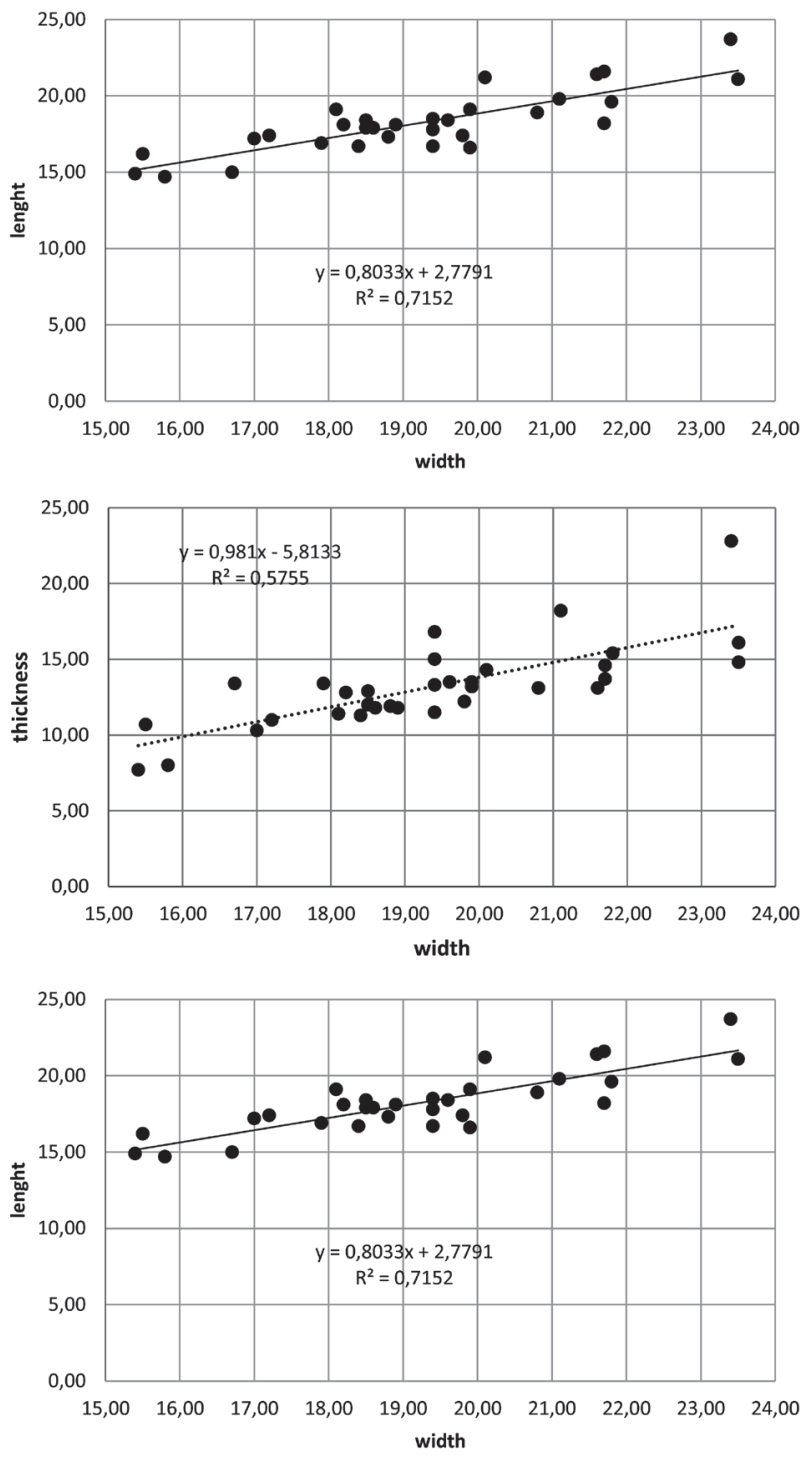

Figure 8. Scatter diagram of 34 specimens of Spirigerellina stoliczkai (Bittner, 1899) with length $v s$. width and thickness $v s$. width.

1899 Terebratula (Dielasma) himalayanum Bittner, p. 25, pl. 5, figs $1-8,10,11$.

1975 Dielasma himalayanum Bittner, 1899. - Siblík, p. 135, pl. 19, figs 1, 3; text-figs 1a, 1b, 2.

1976 “Adygella” himalayana Bittner, 1899. - Jin \& Sun in Jin et al., p. 325, pl. 8, figs 29-32, text-fig. 26.

Figure 7. Spirigerellina stoliczkai (Bittner, 1899). Scale bar $=1 \mathrm{~cm} ; \mathrm{Aa}-\mathrm{e}-$ dorsal, ventral, lateral, anterior, and posterior views, respectively. Specimen E 37/1, MPUM11549. Muth (Spiti, India); Ba-e - dorsal, ventral, lateral, anterior, and posterior views, respectively. Specimen RMA 61/62/6. MPUM 11543; Ca-e - dorsal, ventral, lateral, anterior, and posterior views, respectively. Specimen RMA 62/3. MPUM 11544; Da-e - dorsal, ventral, lateral, anterior, and posterior views, respectively. Specimen RMA 89/10. MPUM11548; Ea-e - dorsal, ventral, lateral, and anterior views, respectively. Specimen RMA 62/1. MPUM 11544; F - detail of the external surface with growing lamellae and faint capillae. Specimen RMA61/62/13, MPUM11544; $\mathrm{Ga}-\mathrm{e}$ - dorsal, ventral, lateral, and anterior views, respectively. Specimen RMA 61/62/12. MPUM 11543; H - spiralium seen from the ventral valve side. Specimen RM17/41, MPUM 11538; Ia-e - dorsal, lateral, anterior, and posterior views, respectively. Specimen RMA 58/1. MPUM 11540. 

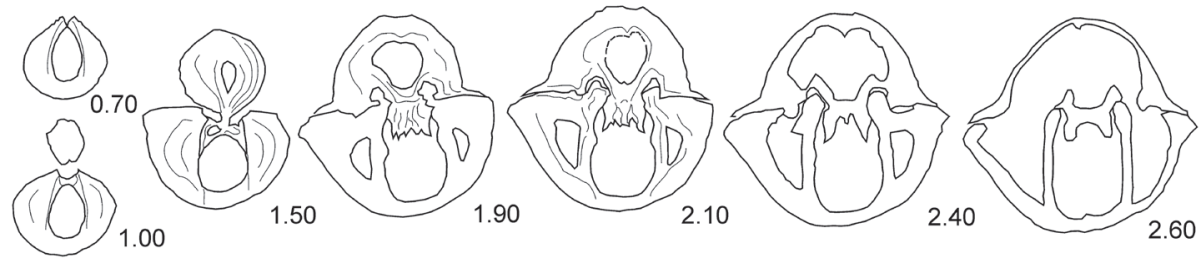

A
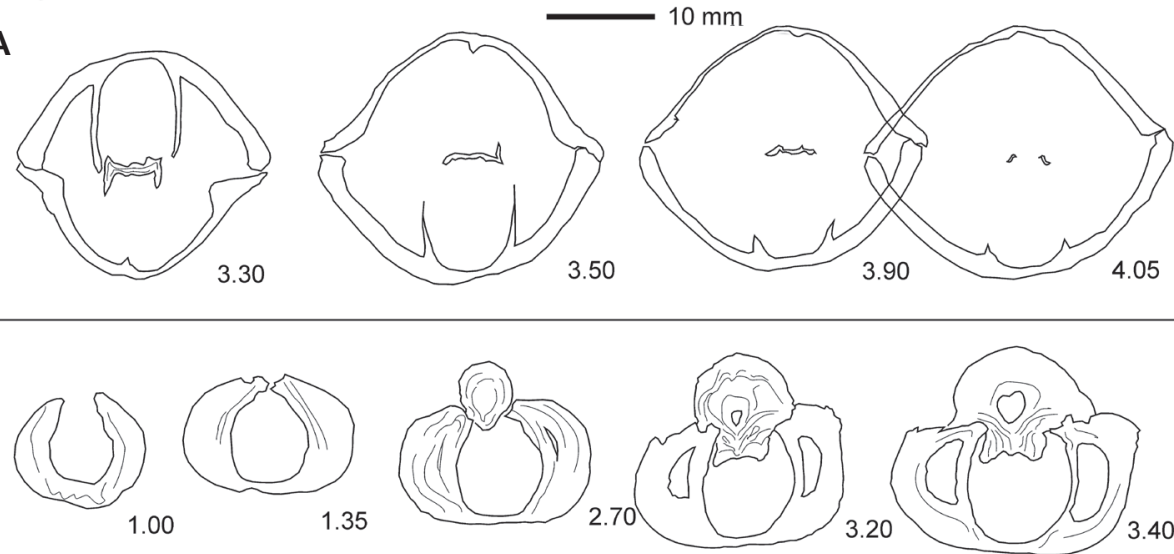

B
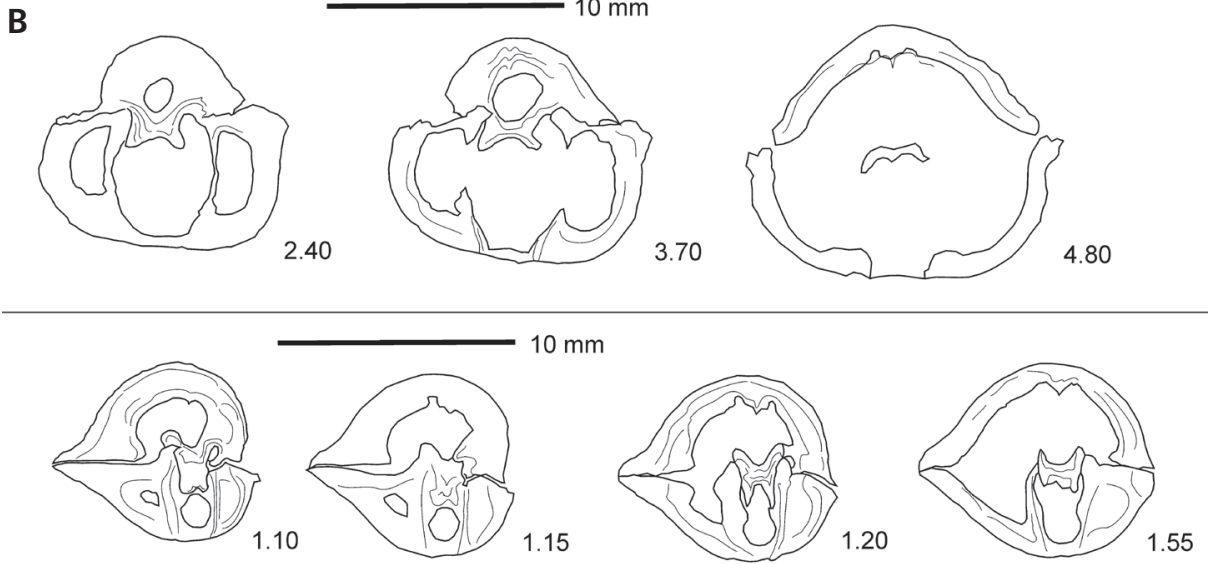

C
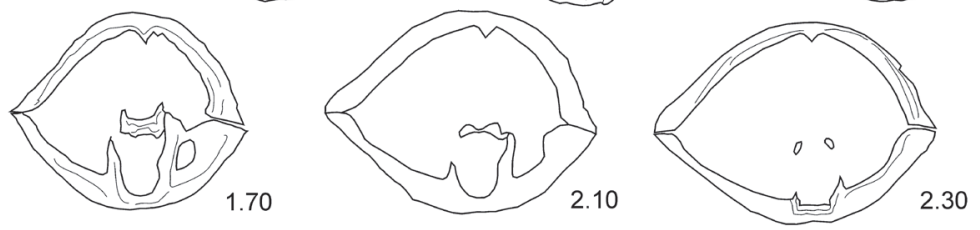

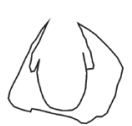

1.40

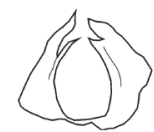

1.70

$10 \mathrm{~mm}$

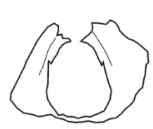

2.00

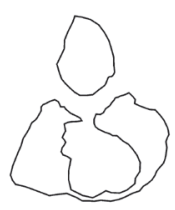

2.30

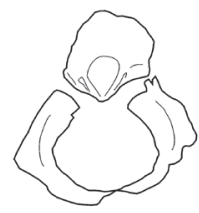

2.90
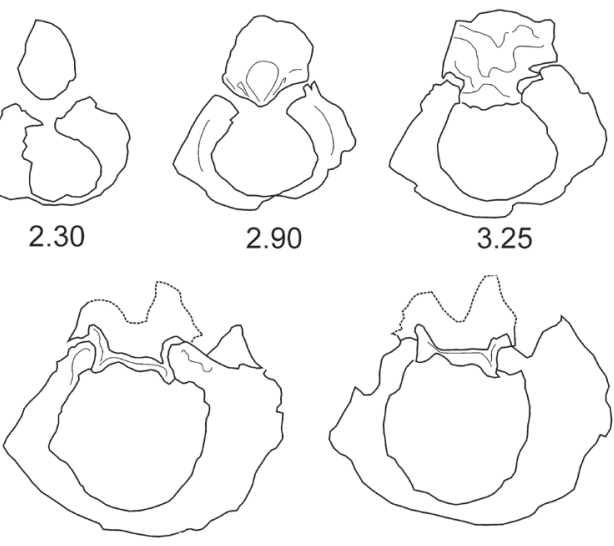

4.50

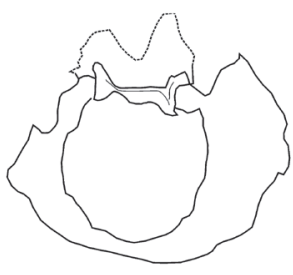

4.80
Figure 10. Spirigerellina stoliczkai (Bittner, 1899). Serial sections. Distance from the umbo in $\mathrm{mm}$. Scale bar $=1 \mathrm{~cm}$. Specimen E 37/2; MPUM 11549, Muth (Spiti, India). 


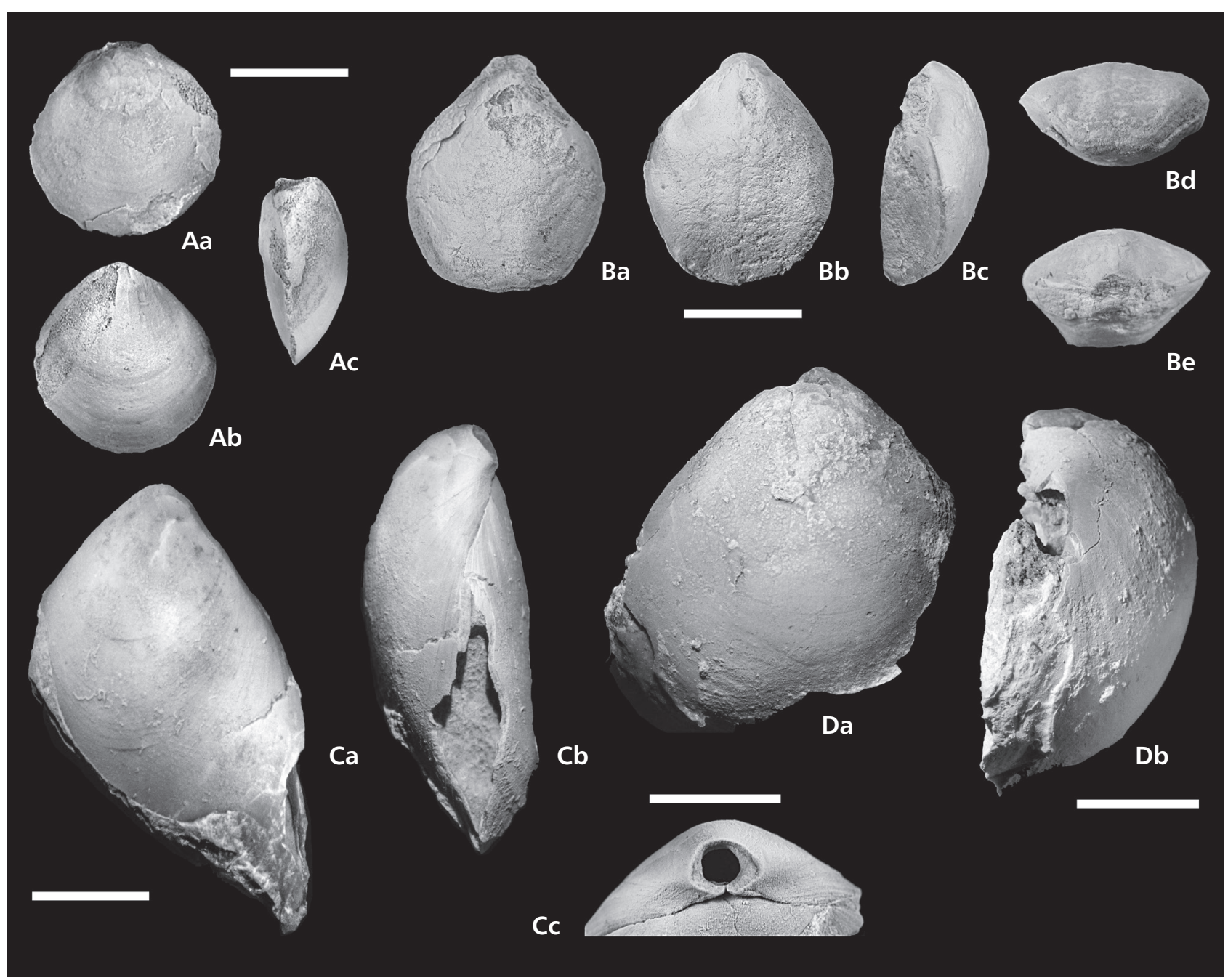

Figure 11. A, B - "Dielasma" himalayanum Bittner, 1899. Scale bar $=1 \mathrm{~cm}$; Aa-c - dorsal, ventral, and lateral, views, respectively. Specimen E $37 / 2$. MPUM 11551; Ba-e - dorsal, ventral, lateral, frontal, and posterior view. Specimen Tulong/1, MPUM 11588. • C, D - Dielasmatid gen. et sp. ind.; $\mathrm{Ca}-\mathrm{c}-$ ventral and lateral views, and detail of the foramen. Specimen 89/20; MPUM 11556; Da, b - ventral and lateral views. Specimen 85bis, MPUM 11555 .

Material. - Muth, Spiti, India (MPUM 11551, E37 2 specimens). Tulong, South Tibet MPUM 11588 (3 specimens).

Remarks. - Due to the scarcity of the material, this species cannot be fully discussed. Some note may be added about the structure of the cardinalia, already described by Siblík (1975). There is a short pedicle collar. The dental plates are posteriorly very near to the valve wall, then almost vertical. The long teeth are obliquely inserted in the sockets, not crenulated, but with developed denticula. The inner hinge plates are directly inserted on the valve floor with no septalium. Strong inner socket ridges. Two high vertical blades, bearing crural process, possibly connected by a rounded band at the front, form the loop. Dimensions (in $\mathrm{mm}$ ) of the "Dielasma" himalayanum Bittner, 1899 are listed in Table 2.
Table 2. Dimensions (in mm) of the "Dielasma" himalayanum Bittner, 1899.

\begin{tabular}{lrcc}
\hline Specimen & Length & Width & Thickness \\
\hline E 37/1 & $>16.50$ & 16.60 & 7.50 \\
E 37/2 & 25.60 & - & 12.50 \\
Tulong/1 & 23.85 & 18.90 & 11.10 \\
Tulong/2 & 21.70 & 18.80 & 14.50 \\
\hline
\end{tabular}

As already pointed out by Bittner (1899), the cardinalia are different from Coenothyris, having septalium. The same holds true for Adygella (Siblík 1975). Cardinalia are very similar to Dielasma, a genus present in the Pennsylvanian to Permian. For this reason, the generic name is within inverted comers. Probably a new genus, but the material at disposal is not sufficient. Tibetothyris Jin \& Sun, 1976 differs for the sulcuplicate to bisulcate shell. 

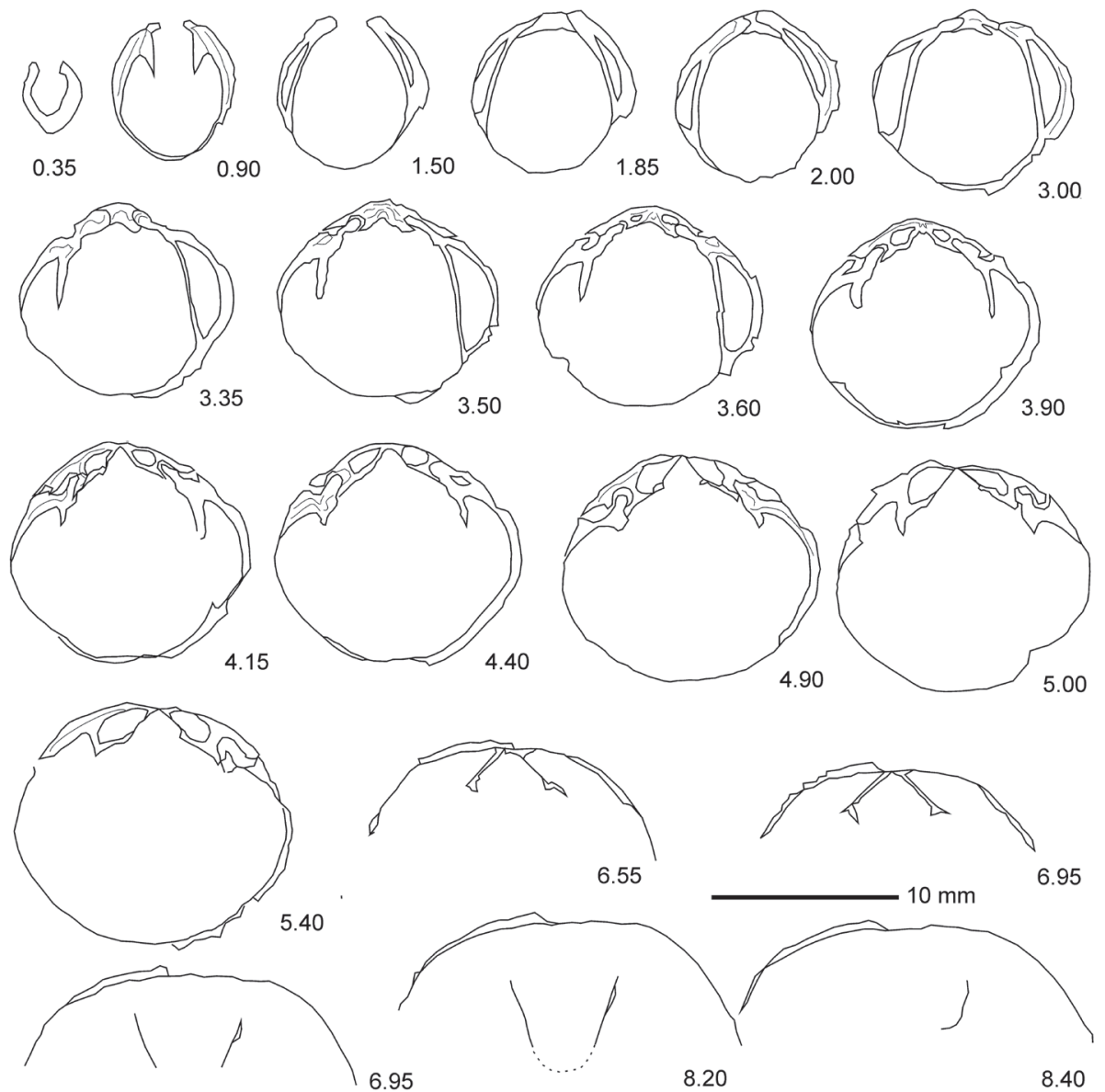

Figure 12. "Dielasma" himalayanum Bittner, 1899. Serial sections. Distance from the umbo in $\mathrm{mm}$. Scale bar $=1 \mathrm{~cm}$. Specimen E 37/2, MPUM 11551, Muth (Spiti, India).
Occurrence. - "Dielasma" himalayanum was reported from the Tamba Kurkur Fm. in Zanskar (western Himalaya), from the Muschelkak of Rimkin Payar and Rajhoti Pass (Central Himalaya), Lalung (Lilang) in Spiti (Bittner 1899) and from Dolpo (Nepal) (Siblík 1975). Our figured specimens are from the top of the Himalayan Muschelkalk at Muth (Spiti) and from the lower part of the Qudenggongba Fm. (Tulong, South Tibet), belonging to the Bithynian/Pelsonian in Himalaya.

\section{Genus Adygella Dagys, 1959}

Type species. - Adygella cubanica Dagys, 1959. Norian of Northwestern Caucaus, Russia.

Adygella socotrana sp. nov.

Figures 13A-E, 14, 15
Types. - Holotype, specimen MPUM11552, RM23/3. Paratypes, the 60 specimens MPUM11553 from bed RM23.

Type horizon and locality. - Adygella socotrana assemblage, Ras Momi section.

Material. - Socotra, Ras Momi section: MPUM11553, RM23 (61 spec.); MPUM 11554, RMA37 (7 spec.). Specimens are usually articulated.

Etymology. - From the island of Socotra.

Diagnosis. - Medium to large sized dielasmatid, biconvex. Uniplicate in adult specimens, Smooth shell. Dental lamellae, septalium supported by short stout septum. No ventral septum.

Description. - Medium to large sized dielasmatid,

Figure 13. Adygella socotrana sp. nov. Scale bar $=1 \mathrm{~cm}$; Aa-e - dorsal, ventral, lateral, anterior, and posterior views, respectively. Holotype. Specimen RMA 23/2, MPUM 11552; Ba-e - dorsal, ventral, lateral, anterior, and posterior views, respectively. Paratype. Specimen RMA 23/1, MPUM 11553; $\mathrm{Ca}-\mathrm{e}$ - dorsal, ventral, lateral, anterior, and posterior views, respectively. Paratype. Specimen RMA 23/2, MPUM 11553; Da-e - dorsal, ventral, lateral, anterior, and posterior views, respectively. Paratype. Specimen RMA 37/1, MPUM 11554; E - detail of the umbo, foramen with pedicle collar. Paratype. Specimen RMA 23/2, MPUM 11553; Fa-e - dorsal, ventral, lateral, anterior, and posterior views, respectively. Specimen RMA 37/3, MPUM 11554. 


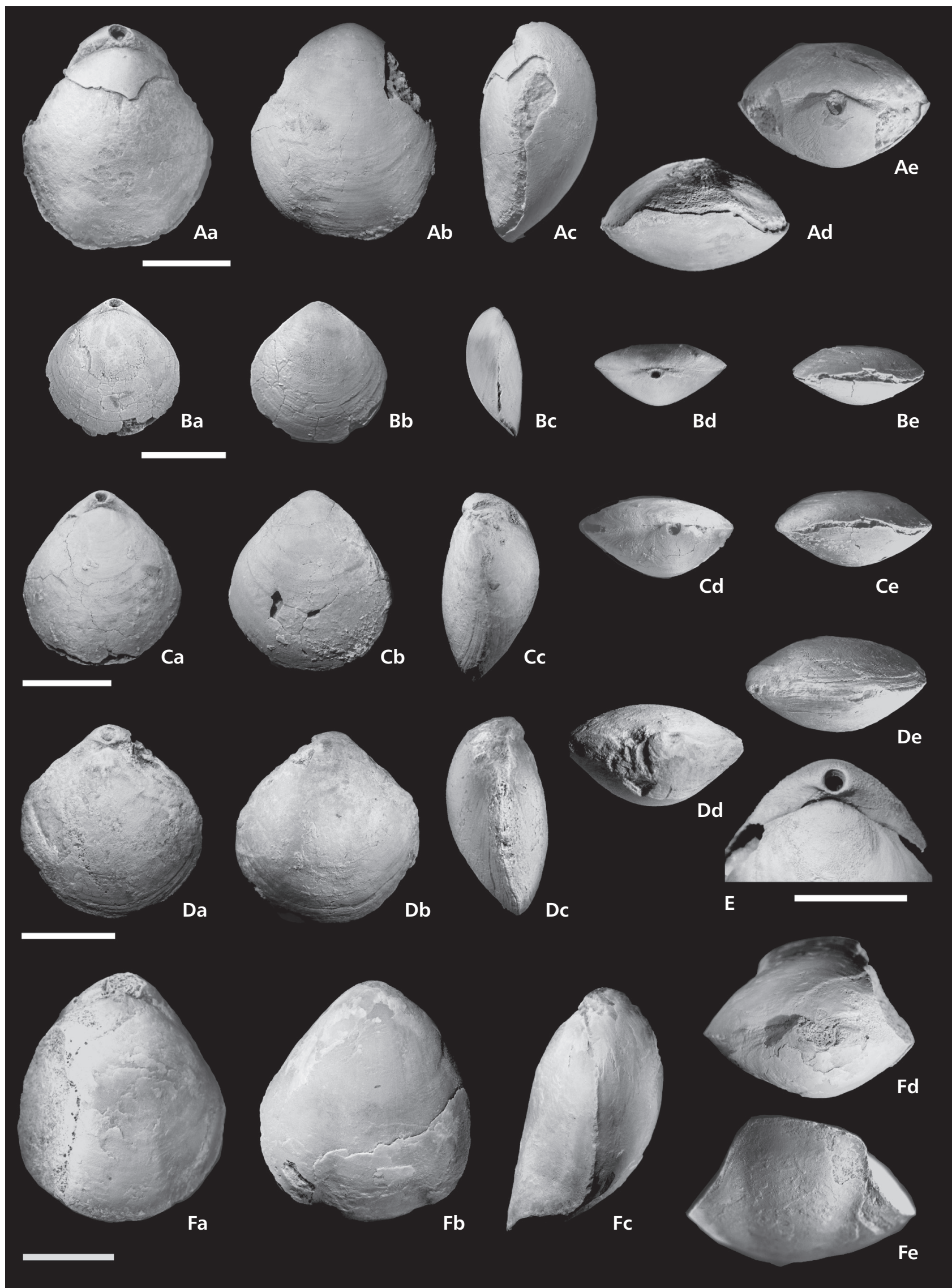


biconvex; length similar to the width in the juveniles, progressively longer. Anterior commissure rectilinear in the juveniles, uniplicate in the adults with fold and sulcus identified from the $2 / 3$ of the length. Beak short with rounded ridges. Rounded, medium sized foramen at the apex of the beak. Shell smooth, with very faint growing lamellae. Endopunctation visible. Most of the specimens are distorted or crashed because of the delicate shell (Table 3).

Internal characters: Dorsal valve with pedicle collar rounded and complete. Thin oblique dental lamellae, delimiting a trapezoidal delthyrial cavity. Teeth rounded and not crenulated, inserted obliquely in the sockets. External denticula well developed.

Ventral valve with inner hinge plates subhorizontal, fixed to a very low septalium supported by stout buttress. Hinge plates subhorizontal, short with high inner socket ridge. Figure 15 shows the internal structures of a larger
Table 3. Dimensions (in mm) of the Adygella socotrana sp. nov.

\begin{tabular}{lccc}
\hline Specimen & Length & Width & Thickness \\
\hline RM 23/1 & 16.5 & 15.9 & 8.6 \\
RM 23/2 & 19.9 & 18.1 & 9.0 \\
RM 23/3 & 25.3 & 22.2 & - \\
RMA 37/1 & 21.6 & 20.6 & 11.7 \\
RMA 37/2 & 21.9 & 16.1 & 10.4 \\
RMA 37/3 & 26.9 & 23.5 & 16.3 \\
RMA 89 & 14.8 & 12.9 & 8.7 \\
\hline
\end{tabular}

specimen, where the inner hinge plates are nearly fixed to the wall, with almost no septalium. We interpret the feature as linked to the size and to the angle of cutting of the section. Crura developed to form a vertical lamina. Loop not preserved.
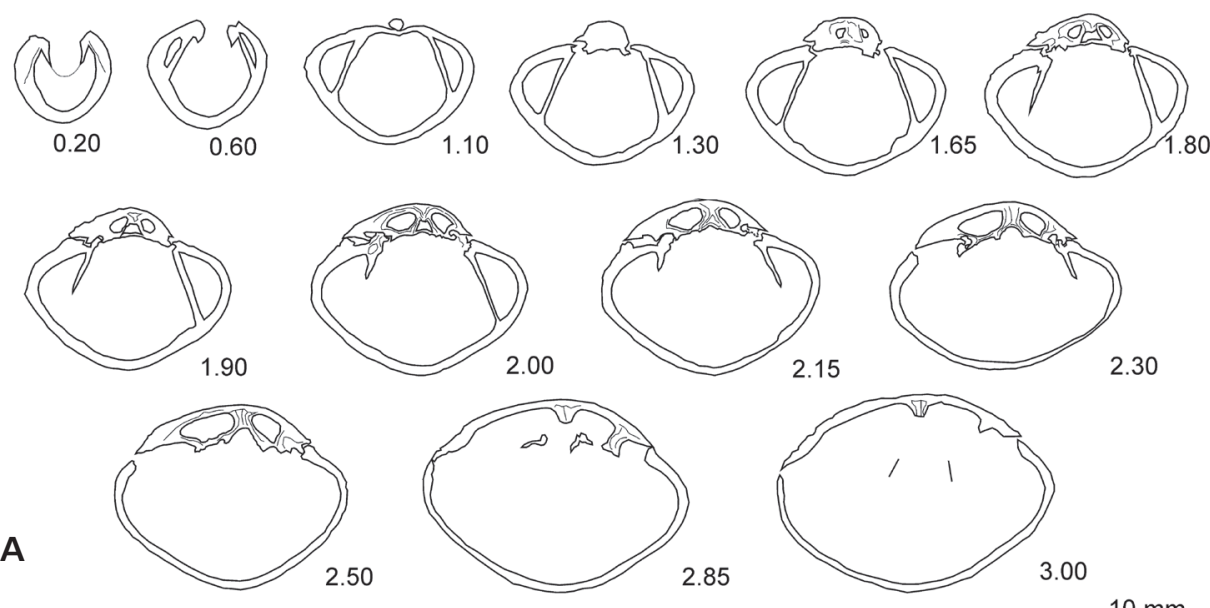

2.30

A

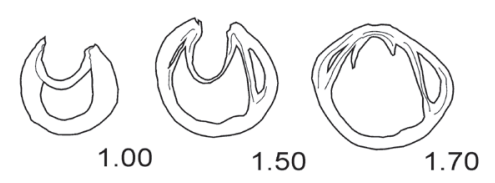

$10 \mathrm{~mm}$
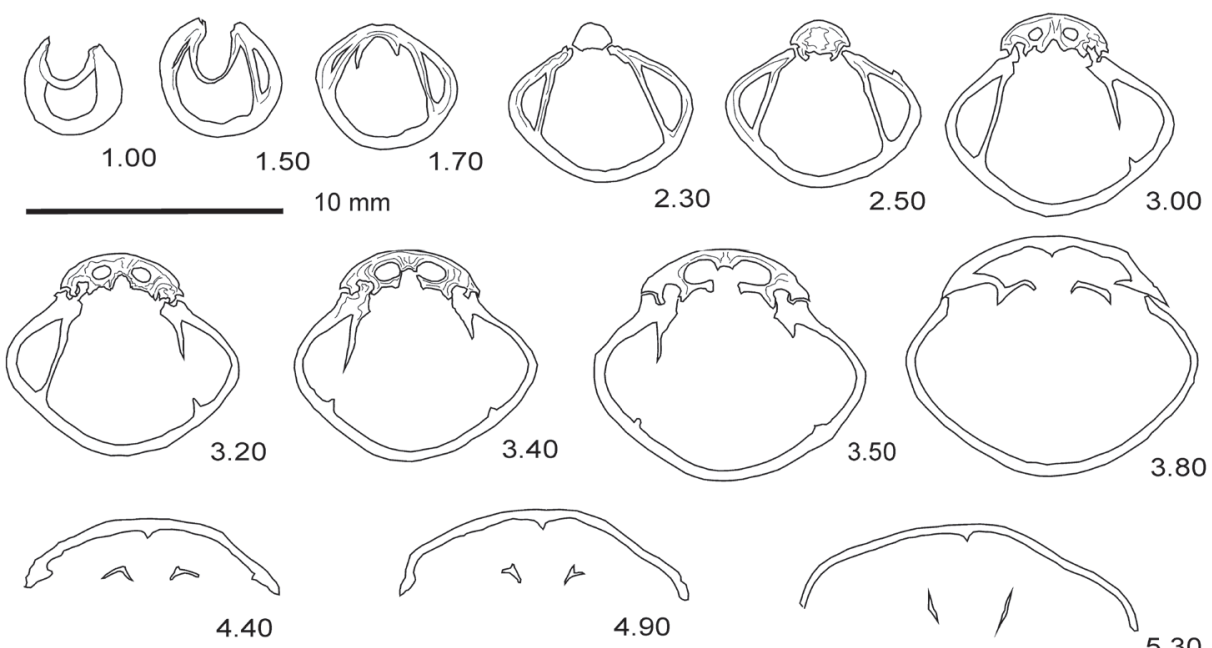

B

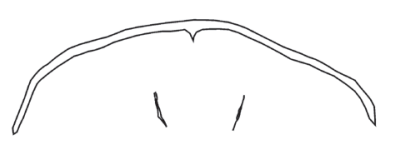

6.20

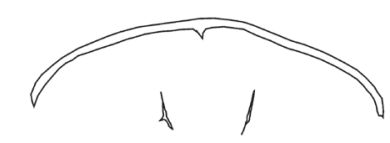

Figure 14. Adygella socotrana $\mathrm{sp.}$ nov. Serial sections. Distance from the umbo in $\mathrm{mm}$. Scale bar $=1 \mathrm{~cm}$; A - specimen RM 23/a, MPUM 11553; B - specimen RM 23/b, MPUM11553. 
Figure 15. Adygella socotrana sp. nov. Serial sections. Distance from the umbo in $\mathrm{mm}$. Scale bar $=1 \mathrm{~cm}$. Specimen RM37, MPUM11554.
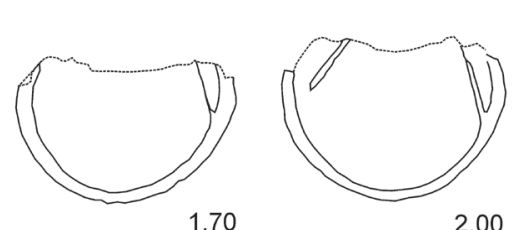

2.00
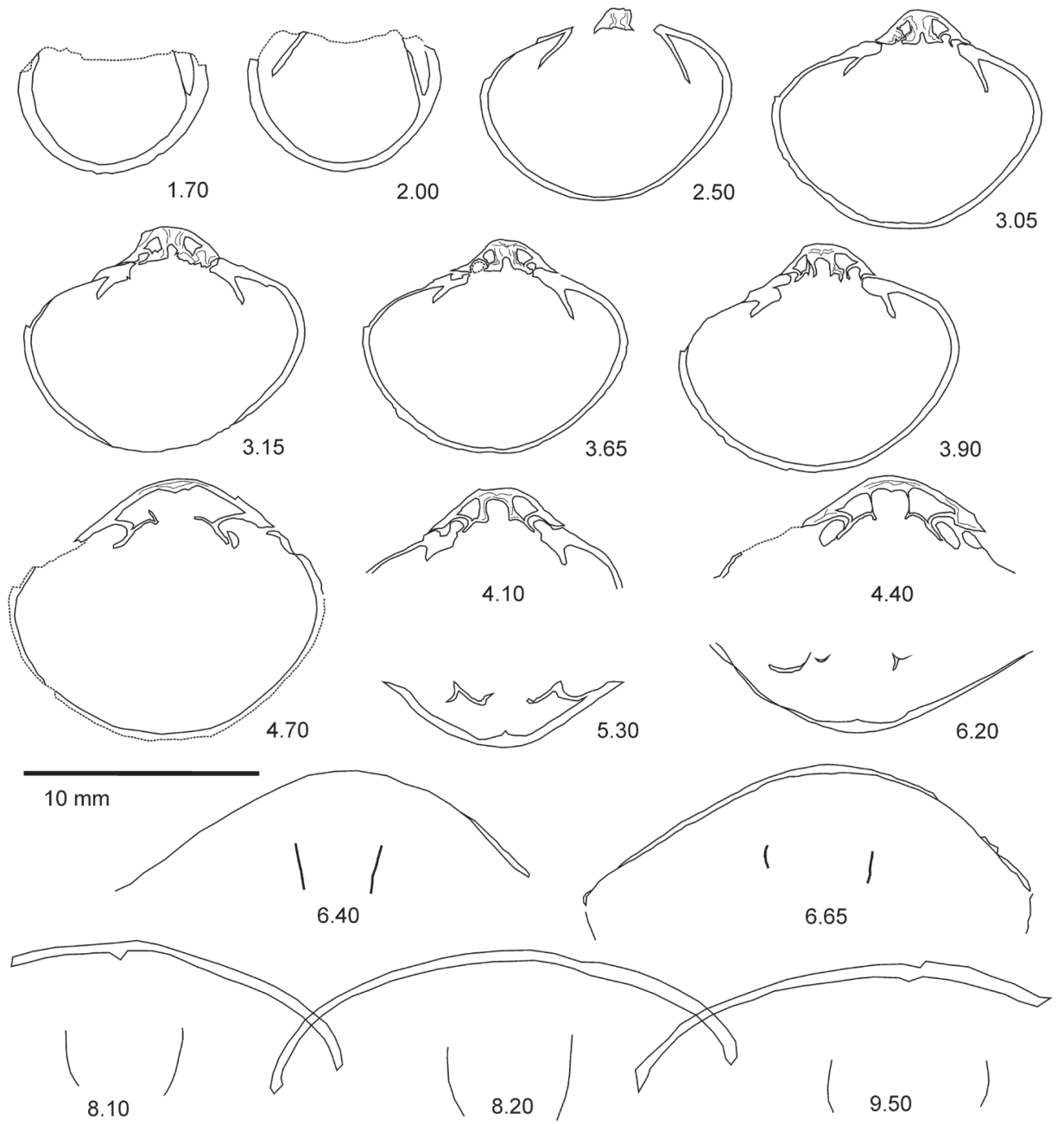

Remarks. - A. socotrana differs from "Dielasma" himalayanum in the structure of dorsal cardinalia, bearing a septalium supported by a buttress. " $D$." himalayanum instead, as already figured by Siblík (1975), has oblique thin inner hinge plates directly fixed to the valve floor, without septalium. In A. cubanica, type species of Adygella, the septalium in high, while in $A$. socotrana is short. This feature approaches A. socotrana to the genus Coenothyris, spread in the Middle Triassic. However, Coenothyris has well developed cardinal process and persistent long median septum in the ventral valve, absent in A. socotrana. Adygella elongata Yang \& Xu, 1966 has higher septum supporting the septalium, as do Adygella pentagonalis Jin \& Sun in Jin et al. (1976).

Occurrence. - Adygella socotrana sp. nov. is abundant in the lower brachiopod assemblage (RMA37, RM23). Bithynian age.

\section{Dielasmatid gen. et sp. ind.}

Figure 11C, D

Material. - Incomplete or fragmentary specimens, nonarticulated ventral valves. MPUM 11587, RMA75bis (1 articulate spec.); MPUM11555, RMA85bis (2 spec.); MPUM 11556, RMA 89 (2 juvenile complete specimens and 4 fragments).

Description. - Large smooth dielasmatid, exceeding $35 \mathrm{~mm}$ both in length and in width. Ventral valve thicker than the dorsal. Foramen with developed pedicle collar.

Remarks. - The material at hand does not allow a complete identification and description. It is kept separate from A. socotrana because of its larger size, the higher angle at the shoulder. The age is different, Bithynian for $A$. socotrana vs. Early Ladinian for this species. 
Occurrence. - Topmost part of the section, from 103 to $\mathrm{m}$ 106 (Fig. 2).

\section{Comparison between Socotra and Himalaya brachiopod faunas}

The fauna of Socotra has strict counterparts in Himalaya, distributed along the ancient fringe of the Indian Plate during the Triassic, facing the Neo-Tethys Ocean (Gaetani \& Garzanti 1991, Garzanti 1999, Sciunnach \& Garzanti 2012). The overall Anisian marine succession of Himalaya is viewed as a persistent lateral developing marine succession, consisting of thin-bedded nodular limestone, often bundled together in massive beds that also form cliffs. These facies are replaced by bedded nodular limestones, with more erodible marly intercalations, around the Bithynian-Pelsonian boundary. Different formational names have been adopted, like Tamba Kurkur Fm. (Zanskar), Himalayan Muschelkalk (Spiti), and Qudenggongba Fm. (South Tibet). In general, they represent a progressive deepening of the Indian margin during the Anisian, resulting in a deep shelf environment, with low sedimentation rate and occasional hiatuses and condensations (Sciunnach \& Garzanti 2012).

Brachiopods are always a minor component of the Anisian faunas of Himalaya. They were firstly collected and described at the beginning of the Himalayan reconnaissance of stratigraphy (Stoliczka 1866), and subsequently monographed by Bittner (1899) and Diener (1907) in Kashmir, Spiti, and Kumaon. Later, brachiopods were occasionally sampled and studied in Dolpo (Nepal) (Siblík 1975, Fuchs 1977), and with little sampling in Zanskar (Gaetani et al. 1986) and Spiti (India) (Krystyn et al. 2004). Chinese researchers performed further collection and taxonomy in South Tibet (Jin et al. 1976, Chen 1983, Yin 2003).

Although the brachiopod faunas of Himalaya and Socotra have some species in common, they lived in different environmental conditions. The Socotra brachiopods dwelled in shallow water, often under the influence of waves. Density of specimens is high to very high, and the diversity low. The Bithynian assemblage consists of a single species, Adygella socotrana, while the Illyrian is dominated by Spirigerellina stoliczkai, with minor occurrence of Lepismatina lilangensis and Nudirostralina mutabilis. Specimens may be coated by algal or bryozoans encrustations, and their internal structure is often broken, suggesting high-energy conditions. On the other hand, the Himalayan fauna, in Kashmir (Diener 1907), Zanskar (Gaetani et al. 1986), Spiti (Bittner 1899), and Dolpo (Siblík 1975), has higher diversity and lower density of the specimens. Brachiopods are not frequent and only slightly more abundant at the top of the Himalayan
Muschelkalk, where the lower sedimentation rate locally allowed a higher density of the buried specimens. This indicates an environment deeper than in Socotra, certainly below the storm wave base.

A difference between Himalaya and Socotra exists also in the time distribution of the brachiopods. In Himalaya the sea-bottom deepened quickly after the deposition of the Himalayan Muschelkalk and its lateral equivalents, making the environment less viable for brachiopods during the Late Anisian. In Socotra instead, the environment did not changed significantly, as it became just a bit richer in clay toward the upper part of the interval. Therefore, some brachiopod species could survive also during the Late Anisian.

\section{Socotra-Himalaya connection during the Middle Triassic}

The affinity of the brachiopod fauna of Socotra with that of the Himalaya is a splendid example for a palaeobiogeographic analysis, as it allows an accurate reconstruction of the evolution of the southern Tethyan margin during the Triassic (Fig. 16).
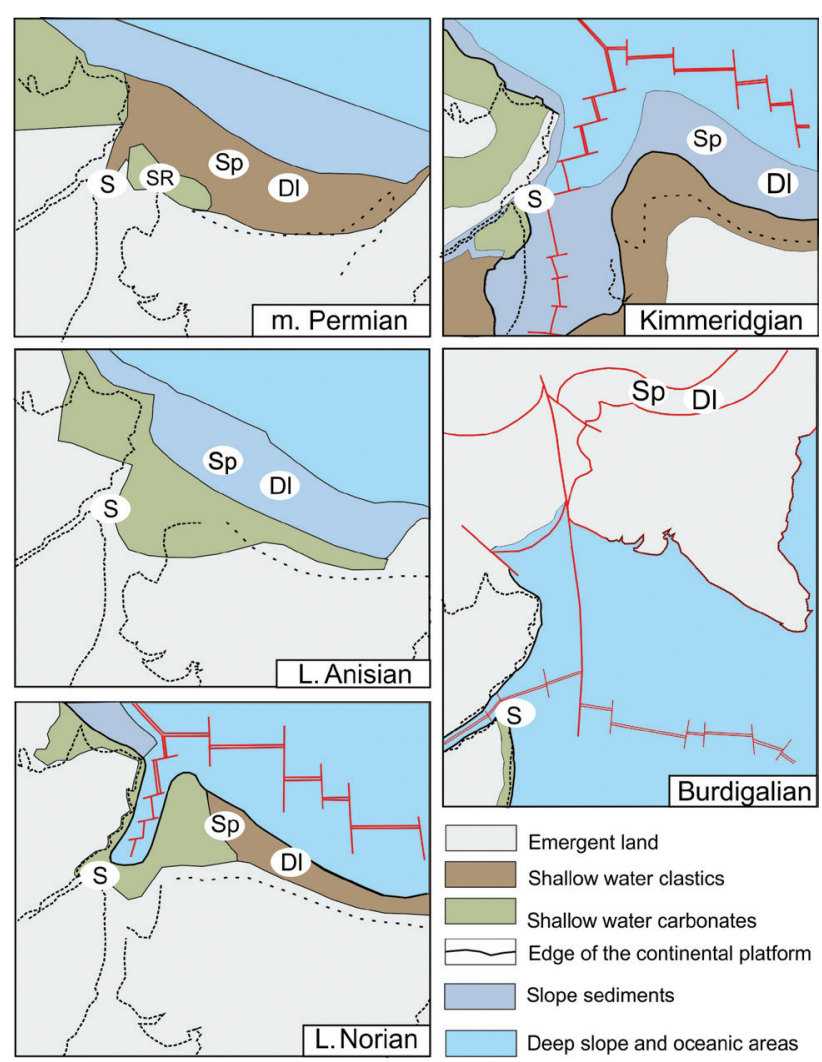

Figure 16. Cartoons showing the palaeogeographic displacements suffered by the Triassic of Socotra (from Dercourt et al. 1993, simplified). Abbreviations: D1 - Dolpo; S - Socotra; Sp - Spiti; Sr - Salt Range; St - South Tibet. 
During the Paleozoic, the Afro-Arabian and the Indian plates were all merged in a single continental mass, which was part of the Gondwanaland. During the Permian, after the Gondwana glaciations, the sea transgressed onto the marginal areas of this supercontinent, as observed in Oman (Angiolini at al. 2003, Richoz et al. 2005) and in the present Himalaya (Gaetani et al. 1986, Archbold \& Gaetani 1993; among others). The Neo-Tethys Ocean initiated its existence and started spreading, as shown by the repeated episodes of rifting detected in the marginal areas (Sciunnach \& Garzanti 1996, 2012). These changes, however, are not recorded in Socotra, as it was still in a continental environment at that time. With the Triassic, the thermal cooling of the southern Tethyan margin increased its subsidence and reached fully open marine conditions along the future Himalayan margin (Garzanti et al. 1996, Garzanti 1999, Krystyn et al. 2004). Therefore, a marine ingression was possible also at Socotra, as it formed the westward prosecution of the margin, where the first marine deposits are dated as early Olenekian. Other episodic transgressions occurred during the Anisian and the Early Ladinian forming shallow carbonate deposits, which continued until the Late Triassic, as testified by the bedded dolostone in the Ras Falanj area.

Between the end of the Triassic and the lowermost Jurassic, rifting occurred along the Oman-Somalia alignment, beginning the separation of Socotra from the Himalayan margin (Bosellini 1989). The opening of the North Somalian basin started with the M22 magnetic anomaly (150 Ma), inducing the split of the MadagascarSeychelles-India block (Bosellini 1992, Marquer et al. 1998). The Indian Ocean began to open from the AfricanArabian block, along a sinistral transform fault between Madagascar and the Seychelles (Patriat \& Achache 1984, Schettino \& Scotese 2005). This structure possibly extended along the eastern Oman margin, thus accommodating the rapid motion of India to the north, since the Chron 34 (83.5 Ma; Schettino \& Scotese 2005). Consequently, the part of the continental margin including Socotra remained on the west side of the newly formed mid-oceanic ridge. Socotra laid near the present day Southern Oman, possibly along the Dofhar Mountains, with which it shares the crystalline basement (Lepvrier et al. 2002), and continued to stay attached to the Arabian Peninsula until the beginning of the Miocene (d'Acremont et al. 2005). When the Gulf of Aden started opening, Socotra separated from Oman and remained on the southern side of the oceanic ridge, loosely linked to the eastern African spur, the Somali Plateau (Fournier et al. 2007, Leroy et al. 2013). Since the late Eocene, the Gulf of Aden represents a good example of oblique rifting (Lepvrier et al. 2002, Leroy et al. 2013). Its activity increased during the early Miocene and continued until the present (Platel \& Roger 1989, Leroy et al. 2013).

\section{Conclusions}

The sedimentary succession of the Socotra Island testifies the occurrence of episodic marine ingressions along the southern Tethyan margin during the Early and Middle Triassic. Three distinct brachiopod assemblages are recognized within specific intervals of this succession, and have been dated by the co-occurring conodont assemblages as Bithynian, Illyrian, and Ladinian, respectively. Taphonomic features indicate that these brachiopods lived in a shallow water environment with high-energy.

The brachiopod fauna of Socotra is also compared with a few specimens from the Anisian of Spiti and South Tibet (Himalaya, India, and China), in order to verify a possible faunal affinity between Socotra and Himalaya. Despite the difference in the sedimentary environment, Socotra and Himalaya were connected during the Anisian, as both were part of the fringe of the Gondwanaland, facing the opening Neo-Tethys. As consequence of the repeated episodes of Gondwana splitting, Socotra remained attached to the African Plate, as the easternmost tip of the Somali Plateau. On the other hand, India drifted away, to eventually collide with the Asian margin during the Cenozoic and build the Himalayan mountain range.

\section{Acknowledgements}

Field works were carried out in 2004 and 2005 with special permission of the Ministery of Tourism and Environment of Yemen. Organization of the field activity was done in close cooperation with director and staff of UNDP "Socotra Conservation and Development Programme". We are deeply indebted with Abdel Kader Ben Sada (SCDP) for the encouragment and suggestions and the geologist Mohammed Najeeb, who shared with us the field work. E. Garzanti kindly provided some specimens from Tulong. Giovanni Chiodi and Gabriele Pezzi helped with text figures and plates. Stefano Dominici and Elisabetta Cioppi of the Museo di Storia Naturale di Firenze assisted in the analysis of the Parona' material. The Reviewers Attila Vörös (Budapest) and Josef Michalík (Bratislava) are warmly thanked for their helpful and constructive criticism.

Adygella socotrana sp. nov. Gaetani, in Gaetani et al. has been registered in the ZooBank database: urn:1sid:zoobank. org:act:13D4EA88-C8F5-4F96-8CE6-8E87FB2281E9.

\section{References}

Acremont, E. D', Leroy, S., Beslier, M.O., Bellahsen, N., Fournier, M., Robin, C. \& Gente, P. 2005. Structure and evolution of the eastern Gulf of Aden conjugate margins 
from seismic reflection data. Geophysical Journal International 160(3), 869-890.

DOI 10.1007/978-3-642-30609-9-20

Alvarez, F., Rong, J.Y. \& Boucot, A.J. 1998. The classification of Athyridid brachiopods. Journal of Paleontology 72(5), 827-855. DOI 10.1017/S0022336000027189

Angiolini, L., Balini, M., Garzanti, E. \& Tintori, A. 2003. Gondwanan deglaciation and opening of Neotethys: The Al Khlata and Saiwan Formations of Interior Oman. Palaeogeography, Palaeoclimatology, Palaeoecology 196(1), 99-123. DOI 10.1016/S0031-0182(03)00315-8

Archbold, N.W. \& GaETANi, M. 1993. Early Permian Brachiopoda and Mollusca from the Northwest Himalaya, India. Rivista Italiana Paleontologia Stratigrafia 99(1), 30-52.

Balini, M., Gaetani, M., Giorgioni, M., Nicora, A. \& Pavia, G. 2008. Bio-chronostratigraphy and sequence stratigraphic interpretation of the Triassic succession of Socotra Island, Yemen. $8^{\text {th }}$ Middle East Geosciences Conference, GEO 2008. GeoArabia Abstract 13(1), p. 132.

Banner, F.T., Whittaker, J.E., Boudagher-Fadel, M.K., SAmuel, M.A. \& Jonas, R.W. 1997. Socotraina, a new Hauraniid genus from the Lias of Middle East (Foraminifera textulariina). Revue de Micropaléontologie 40(2), 115-123. DOI 10.1016/S0035-1598(97)90514-6

Beydoun, Z.R. \& Bichan, H.R. 1969. The geology of Socotra Island, Gulf of Aden. Quarterly Journal of the Geological Society 125, 413-441. DOI 10.1144/gsjgs.125.1.0413

BitTner, A. 1890. Brachiopoden der alpinen Trias. Abhandlungen der Kaiserlich-königlichen Geologische Reichsanstalt, 14, 1-325.

BittNer, A. 1898. Beiträge zur Paläontologie, in besondere der triadische Ablagerungen zentralasiatischer Hochgebirge. Jahrbuch der Kaiserlich-königlichen Geologische Reichsanstalt 48, 689-718.

BittNer, A. 1899. Trias Brachiopoda and Lamellibranchiata. Palaeontologia Indica 15(3/2), 1-76.

Bosellini, A. 1989. The continental margin of Somalia: their structural evolution and sequence stratigraphy. Memorie Scienze Geologiche Padova 39, 373-458.

Bosellini, A. 1992. The Continental Margins of Somalia: structural evolution and sequence stratigraphy. American Association Petroleum Geologists, Memoir 53, 185-205.

Boucot, A.J., Johnson, J.G. \& Staton, R.D. 1964. On some Atrypoid, Retzioid, and Athyridoid brachiopoda. Journal of Paleontology 38(5), 805-822.

Brack, P., Rieber, H., Nicora, A. \& Mundil, R. 2005. The Global Boundary Stratotype Section and Point (GSSP) of the Ladinian Stage (Middle Triassic) at Bagolino (Southern Alps, Northern Italy) and its implications for the Triassic time scale. Episodes 28, 233-244.

Chen, Y.M. 1983. New advance in the study of Triassic brachiopods in the Tulong District of the Nyalam County, Xizang (Tibet). Contribution to the Geology of the QinghaiXizang Plateau 11, 145-156. [in Chinese]

Dagys, A.S. 1959. Upper Triassic Brachiopods from the south of the USSR. 248 pp. Izdatelstvo Akademii Nauk SSSR, Moscow. [in Russian]

DAGYs, A.S. 1972. Yavleniya metakhoreza sredi triasovykh spiriferinid. Trudy Instituta Geologii i Geofiziki 111, 1-36.

DAGYs, A.S. 1974. Triassic Brachiopods (morphology, classification, phylogeny, stratigraphical significance and biogeography). Trudy Instituta Geologii i Geofiziki 214, 1-378. [in Russian]

DAVIDSON, T. 1881. On genera and species of spiral-bearing brachiopoda, from specimens developed by the Rev. Norman Glass: with notes on the results obtained by Mr George Maw from extensive washings of the Wenlock and Ludlow Shales of Shropsire. Geological Magazine 8(1), 1-13. DOI 10.1017/S0016756800112993

Dercourt, J., Ricou, L.E. \& Vrielynck, B. 1993. Atlas Tethys Palaeoenvironmental Maps. 307 pp. Gauthier-Villars, Paris.

Diener, C. 1907. The fauna of Himalayan Muschelkalk. Palaentologia Indica 15(5, 2), 11-140.

DumériL, A.M.C. 1806. Zoologie analytique ou méthode naturelle de classification des animaux. 344 pp., XXIV Allais, Paris.

Fournier, M., Huchon, P., Khanbari, K. \& Leroy, S. 2007. Segmentation and along-strike asymmetry of the passive margin in Socotra, eastern Gulf of Aden: Are they controlled by detachment faults? Geochemistry, Geophysics, Geosystems 8(3), Q03007. DOI 10.1029/2006GC001526

Fuchs, G. 1977. The Geology of the Karnali and Dolpo Regions, Western Nepal. Jahrbuch Geologisches Bundesanstalt 120(2), 165-217.

GAETANI, M. 1969. Osservazioni paleontologiche e stratigrafiche sull'Anisico delle Giudicarie (Trento). Rivista Italiana Paleontologia Stratigrafia 75(3), 469-546.

Gattani, M. \& Garzanti, E. 1991. Multirifting history of the north Indian margin in Himalaya. American Association of Petroleum Geologists Bulletin 75, 1427-1446.

Gaetani, M., Casnedi, R., Fois, E., Garzanti, E., Jadoul, F., NicorA, A. \& Tintori, A. 1986. Stratigraphy of Tethys Himalaya in Zanskar, Ladakh. Initial Report. Rivista Italiana Paleontologia Stratigrafia 91(3), 443-478.

Garzanti, E. 1999. Stratigraphy and sedimentary history of the Nepal Tethys Himalaya passive margin. Journal of Asian Earth Sciences 17(5), 805-827.

DOI 10.1016/S1367-9120 (99)00017-6

Garzanti, E., Angiolini, L. \& Sciunnach, D. 1996. The MidCarboniferous to lowermost Permian succession of Spiti (Po Group and Ganmachidam Formation; Tethys Himalaya, Northern India): Gondwana glaciation and rifting of NeoTethys. Geodinamica Acta 9(2), 78-100. DOI 10.1080/09853111.1996.11105279

Garzanti, E., Nicora, A. \& Rettori, R. 1998. Permo-Triassic boundary and Lower to Middle Triassic in South Tibet. Journal of Asian Earth Sciences 16, 143-157. DOI 10.1016/S0743-9547(98)00007-5

Giongioni, M. 2006. La successione triassica dell'Isola di Socotra 
(Yemen). 85 pp. Master thesis, Università di Milano, Milan, Italy.

Ivanova, E.A. 1972. Main features of Spiriferid evolution (Brachiopoda). Paleontologicheskii Zhurnal 3, 28-42. [in Russian]

Jin, Y.G., Sun, D.L. \& RonG, J.Y. 1976. Mesozoic and Cenozoic brachiopods from the Mt. Qomolangma region, 271-357. In Xizang Scientific Expedition Team of Chinese Academy of Sciences (ed.) A Report on the Scientific Expedition to the Qomolangma Region (1966-1968), Palaeontology, Part 2. Beijing Science Press, Beijing. [in Chinese]

KING, W. 1859. On Guynia, Dielasma, and Macandrevia, three new genera of Palliobrachiata Mollusca, one of which has been dredged in the Strangford Lough. Proceedings of the Dublin University Zoological and Botanical Association 1(3), 256-262.

KovÁcs, S. 1983. On the evolution of the excelsa-stock in the Upper Ladinian-Carnian (Conodonta, genus Gondolella, Triassic), 107-120. In ZAPFE, H. (ed.) Neue Beiträge zur Biostratigraphie der Tethys-Trias 5.

KovÁcs, S. 1994. Conodonts of stratigraphical importance from the Anisian/Ladinian boundary interval of the Balaton Highland, Hungary. Rivista Italiana Paleontologia Stratigrafia 99, 473-514.

Kozur, H. \& Mostler, H. 1982. Neue Conodontenarten aus dem Illyr und Fassan der Profile Fellbach und Karalm (Gailtaler Alpen, Karnten, Osterreich). Geologisches Palaeontologisches Mitteilungen Innsbruck 11, 291-298.

Kozur, H., Krainer, K. \& Mostler, H. 1994. Middle Triassic Conodonts from the Southern Karawanken Mountains (Southern Alps) and their stratigraphic importance. Geologisches Palaeontologisches Mitteilungen Innsbruck 19, 165-200.

Krystyn, L. 1983. Das Epidauros-Profil (Griechenland) - ein Beitrag zur Conodonten-Strandardzonierung des tethyalen Ladin und Unterkarn, 231-258. In ZAPFE, H. (ed.) Neue Beiträge zur Biostratigraphie der Tethys-Trias 5.

Krystyn, L., Balini, M. \& Nicora, A. 2004. Lower and Middle Triassic stage and substage boundaries in Spiti. Albertiana 30, 40-53.

Kunn, O. 1949. Lehrbuch der Palaozoologie. 326 pp. Schweizerbart'sche Verlgsbuchhandlung, Stuttgart.

Lepvrier, C., Fournier, M., Bérard, T. \& Roger, J. 2002. Cenozoic extension in coastal Dhofar (southern Oman): implications on the oblique rifting of the Gulf of Aden. Tectonophysics 357, 279-293. DOI 10.1016/S0040-1951(02)00372-4

Leroy, S., Razin, P., Autin, J., Bache, F., Acremont, E. D', Watremez, L., Robinet, J., Baurion, C., Denèle, Y., Bellahsen, N., Lucazeau, F., Rolandone, F., Rouzo, S., Serra Kiel, J., Robin, C., Guillocheau, F., Tiberi, C., Basuyau, C., Beslier, M.O., Ebinger, C., Stuart, G., Ahmed, A., Khanbari, K., AlGanad, I., Clarens, P. de, Unternehr, P., Al-Toubi, K. \& AlLAZKI, A. 2013. From rifting to oceanic spreading in the Gulf of Aden: a synthesis, 385-427. In Al-Hosani K. et al. (eds)
Lithosphere dynamics and sedimentary basins: The Arabian plate and analogues. Springer, Berlin \& Heidelberg.

Marquer, D., Mercolli, I. \& Peters, T. 1998. Early Cretaceous intra-oceanic rifting in the Proto-Indian Ocean recorded in the Masirah Ophiolite, Sultanate of Oman. Tectonophysics 292, 1-16. DOI 10.1016/S0040-1951(98)00063-8

Merla, G., Abbate, E., Azzaroli, A., Bruni, P., Canuti, P., Fazzuoli, M., SAgri, M. \& TAcconi, P. 1979. A geological Map of Ethiopia and Somalia. 95 pp. 2 geological maps, Consiglio Nazionale delle Ricerche, Firenze.

Morrison, J., Birse, A., Samuel, M.A., Richardson, S.M., Harbury, N. \& Bott, W.F. 1997. The Cretaceous sequence stratigraphy of the Socotran Platform, the Republic of Yemen. Marine and Petroleum Geology 14(6), 685-699. DOI 10.1016/S0264-8172(96)00042-6

NiCORA, A. 1977. Lower Anisian platform-conodonts from the Tethys and Nevada: taxonomic and stratigraphic revision. Paleontographica A 157, 88-107.

Nicora, A. \& Brack, P. 1995. The Anisian/Ladinian boundary interval at Bagolino (Southern Alps, Italy): II The distribution of Conodonts. Albertiana 15, 57-65.

Nicora, A., Gaetani, M. \& Garzanti, E. 1985. Late Permian to Anisian in Zanskar (Ladakh, Himalaya). Rendiconti Società Geologica Italiana 7, 27-30.

Orbigny, A. D'1847. Considérations zoologiques et géologiques sur les brachiopods ou palliobranches. Parts 1, 2. Comptes Rendu Hebdomadaires des Séances de l'Académie des Sciences, Paris (2 ${ }^{\text {nd }}$ series) 25(5), 193-195, 266-269.

Parona, C.F. 1928. Faunette triassiche del Caracorum e degli altipiani tibetani. Spedizione Italiana De Filippi, Série II 6, $1-30$.

Patriat, P. \& Achache, J. 1984. India-Eurasia collision chronology has implications for crustal shortening and driving mechanism of plates. Nature 311(5987), 615-621. DOI $10.1038 / 311615 \mathrm{a} 0$

Platel, J.P. \& Roger, J. 1989. Evolution dynamique du Dhofar (Sultanat d'Oman) pendant le Crétacé et le Tertiaire en relation avec l'ouverture du Golfe d'Aden. Bulletin Société Géologique France 8(2), 253-263.

Richoz, S., Baud, A., Krystyn, L., Twitchett, R. \& Marcoux, J. 2005. Permo-Triassic Deposits of the Oman Mountains: from Basin and Slope to the shallow Platform, 1-58. In Richoz, S. \& Baud, A. (eds) Post-conference excursion No. A13, International Association of Sedimentology, 24 $4^{\text {th }}$ Regional Meeting, Muscat.

Salter, J.W. \& Blanford, H.F. 1865. Paleontology of Niti in the Northern Himalaya, being descriptions of the Palaeozoic and Secondary Fossils collected by Col. Richard Strachey. 112 pp. Cutter Military Orphan Press, Calcutta.

Samuel, M.A., Harbury, N., Bott, R. \& Thabet, A.R. 1997. Field observations from the Socotran Platform: their interpretation and correlation to southern Oman. Marine and Petroleum Geology 14(6), 661-673.

DOI 10.1016/S0264-8172 (96)00033-5 
Schettino, A. \& Scotese, C.R. 2005. Apparent polar wander paths for the major continents (200 Ma to the present day): a palaeomagnetic reference frame for global plate tectonic reconstructions. Geophysical Journal International 163, 727-759. DOI 10.1111/j.1365-246X.2005. 02638

Schlotheim, E.F. 1813. Beiträge zur Naturgeschichte der Versteinerungen in geognostichen Hinsicht, 1-134. In Leonhard, C.C. (ed.) Tachenbuch für die gesammte Mineralogie mit Hinsicht auf die neuesrten Entdeckungen 7(1). Hermannschen Buchandlung, Frankfurt am Main.

Schlotheim, E.F. 1816. Beiträge zur Naturgeschichte der Versteinerungen in geognostichen Hinsicht. Denkschriften der Bayerischen Akademie der Wissenschaften 6, 13-36.

Schuchert, C. 1894. A revised classification of the spire bearing Brachiopoda. The American Geologist 13, 102-107.

Schuchert, C. 1913. Class 2. Brachiopoda, 355-420. In Zittel, K.A. von (ed.) Text-book of Palaeontology, vol.1, part 1, $2^{\text {nd }}$ edition. MacMillan \& Co., London.

Sciunnach, D. \& Garzanti, E. 1996. Sedimentary record of Late Paleozoic rift and break-up in Northern Gondwana: a case history from the Thini Chu Group and Tamba-Kurkur Formation (Dolpo Tethys Himalaya, Nepal). Geodinamica Acta 9(1), 41-56. DOI 10.1080/09853111.1996.11417262

Sciunnach, D. \& Garzanti, E. 2012. Subsidence history of the Tethys Himalaya. Earth Science Reviews 111, 179-198. DOI 10.1016/j.earscirev.2011.11.007

Siblík, M. 1975. Triassic brachiopods from Nepal. Rivista Italiana Paleontologia Stratigrafia, 81(2), 133-160.

SToliczKa, F. 1866. Geological sections across the Himalayan Mountains, from Wang-tu Bridge on the River Sutlej to Sumdo on the Indus, with an account of the formation in Spiti; accompanied by a revision of all known fossils from that district. Geological Survey India, Memoirs 5, 1-140.

STUR, D. 1865. Über die Formationen des bunten Sandsteines und des Muschelkalkes in Ober-Schlesien und ihre Versteinerungen von Herrn Dr. phil. Heinrich Eck. Verhandlungen der Kaiserlich-königlichen Geologische Reichsanstalt 15(4), 242-248.

WAagen, W.H. 1883. Salt Range fossils I. Productus - Limestone fossils. Brachiopoda: fasc. 2. Geological Survey of India, Memoirs, Palaeontología Indica, Serie 13 1(4), 391-546.

WANG, Y. 1955. New genera of brachiopods. Acta Palaeontologica Sinica 3, 83-114.
Williams, A., Brunton, C.H.C, Carlson, S.J., Alvarez, F., Ansell, A.D., Baker, P.G., Basset, M.G., Blodgett, R.B., Boucot, A.J., Carter, J.L., Cocks, L.R.M., Cohen, B.L., Copper, P., Curry, G.B., Cusack, M., Dagys, A.S., Emig, C.C., Gawthorp, A.B., Gourvennec, R., Grant, R.E., Harper, D.A.T., Holmer, L.E., Hou, H.F., James, M.A., Jin, Y.G., Johnson, J.G., Laurie, J.R., Lazarev, S., Lee, D.E., Lüter, C., Mackay, S., MacKinnon, D.I., Manceñido, M.O., Mergl, M., Owen, E.E., Peck, L.S., Popov, L.E., Racheboeuf, P.R., Rhodes, M.C., Richardson, J.R., Rong, J.Y, Rubel, M., Savage, N.M., Smirnova, T.N., Sun, D.L., Walton, D., Wardlaw, B. \& Wright, A.D. 2002. Treatise on Invertebrate Paleontology, Part H, Brachiopoda, revised, Vol.4, 921-1688.

Williams, A., Brunton, C.H.C, Carlson, S.J., Alvarez, F., Ansell, A.D., Baker, P.G., Basset, M.G., Blodgett, R.B., Boucot, A.J., Carter, J.L., Cocks, L.R.M., Cohen, B.L., Copper, P., Curry, G.B., Cusack, M., Dagys, A.S., Emig, C.C., Gawthorp, A.B., Gourvennec, R., Grant, R.E., Harper, D.A.T., Holmer, L.E., Hou, H.F., James, M.A., Jin, Y.G., Johnson, J.G., Laurie, J.R., Lazarev, S., Lee, D.E., Lüter, C., Mackay, S., MacKinnon, D.I., Manceñido, M.O., Mergl, M., Owen, E.E., Peck, L.S., Popov, L.E., Racheboeuf, P.R., Rhodes, M.C., Richardson, J.R., Rong, J.Y., Rubel, M., Savage, N.M., Smirnova, T.N., Sun, D.L., Walton, D., Wardlaw, B. \& Wright, A.D. 2006. Treatise on Invertebrate Paleontology, Part H, Brachiopoda, revised, Vol. 5, 1689-2320.

Williams, A., Carlson, S.J., Brunton, H.C., Holmer, L. \& Popov, L. 1996. A supra-ordinal classification of the Brachiopoda. Philosophical Transactions of the Royal Society of London 351, 1171-1193. DOI 10.1098/rstb.1996.0101

Xu, G.R. \& LiU, G.C. 1983. Systematic description. 1. Some problems in the research of Triassic brachiopods. 2. Brachiopods, 67-83, 84-128. In YANG, Z.Y. et al. (eds) Triassic of the South Qilian Mountains. Geological Publishing House, Beijing.

YAnG, Z.Y. \& Xu, G.R. 1966. Triassic brachiopods of Central Guizhou (Kueichow) Province, China. 151 pp. Science Press, Beijing. [in Chinese with English summary]

YIN, H.F. 2003. Triassic biostratigraphy of China, 379-422. In Zhang, W.T., Chen, P.J., Palmer, A.R. (eds) Biostratigraphy of China. Science Press, Beijing. 